\title{
Complementarities in the Search for Innovation Managing Markets and Relationships
}

Grimpe, Christoph; Sofka, Wolfgang

Document Version

Accepted author manuscript

Published in:

Research Policy

DOI:

10.1016/j.respol.2016.07.007

Publication date:

2016

\section{License \\ CC BY-NC-ND}

Citation for published version (APA):

Grimpe, C., \& Sofka, W. (2016). Complementarities in the Search for Innovation: Managing Markets and

Relationships. Research Policy, 45(10), 2036-2053. https://doi.org/10.1016/j.respol.2016.07.007

Link to publication in CBS Research Portal

\section{General rights}

Copyright and moral rights for the publications made accessible in the public portal are retained by the authors and/or other copyright owners and it is a condition of accessing publications that users recognise and abide by the legal requirements associated with these rights.

Take down policy

If you believe that this document breaches copyright please contact us (research.lib@cbs.dk) providing details, and we will remove access to the work immediately and investigate your claim. 


\section{Complementarities in the Search for Innovation: Managing Markets and Relationships}

\section{Christoph Grimpe and Wolfgang Sofka}

Journal article (Accepted version)

CITE: Complementarities in the Search for Innovation: Managing Markets and Relationships. / Grimpe, Christoph; Sofka, Wolfgang. In: Research Policy, Vol. 45, No. 10, २०16, p. २०३6-२०५३.

DOl: 10.1016/j.respol.2016.07.007

Uploaded to Research@CBS: June २०१७

(C) 2017. This manuscript version is made available under the CC-BY-NC-ND 4.0 license http://creativecommons.org/licenses/by-nc-nd/4.0/ 


\title{
COMPLEMENTARITIES IN THE SEARCH FOR INNOVATION -
}

\section{MANAGING MARKETS AND RELATIONSHIPS}

\author{
Christoph Grimpe* \\ Copenhagen Business School \\ Department of Innovation and Organizational Economics \\ Kilevej 14A, 2000 Frederiksberg, Denmark \\ Phone: +45-38152530 \\ Email: cg.ino@cbs.dk \\ Wolfgang Sofka \\ Copenhagen Business School \\ Department of Strategic Management and Globalization \\ Kilevej 14A, 2000 Frederiksberg, Denmark \\ Phone: +45-38152502 \\ Email:ws.smg@cbs.dk
}

* Corresponding author

Published in Research Policy, Vol. 45, No. 10, 2016, p. 2036-2053.

\section{ACKNOWLEDGEMENTS}

The authors thank Pablo D’Este, Alfonso Gambardella, Elena Golovko, Niron Hashai, Keld Laursen, Denisa Mindruta, Elena Novelli, Murat Tarakci, seminar participants at the Universities of Strasbourg and Luxembourg, as well as two anonymous reviewers for excellent feedback and comments. 


\title{
COMPLEMENTARITIES IN THE SEARCH FOR INNOVATION - MANAGING MARKETS AND RELATIONSHIPS
}

\begin{abstract}
Extant research has characterized a firm's search for external knowledge in its innovation activities as either relational or transactional in nature. The former implies that a firm chooses and develops collaborative relationships with knowledge sources like universities, customers or suppliers, while the latter suggests transactions governed by markets for technology. We argue that prior literature has ignored that both search strategies are interrelated and complementary: adopting one strategy has a higher marginal return on innovation performance if the other one is present. Moreover, we suggest the benefits from complementarity to be higher when a firm is more distant to the technological frontier in the industry and when markets for technology in that industry are shallow. We test our hypotheses on a sample of 3,921 German firms from 2001 to 2009 and find support for our hypotheses.
\end{abstract}

Keywords: search strategies, collaboration, markets for technology, innovation performance 


\section{INTRODUCTION}

The question of how firms organize their search for new knowledge and turn it into innovative products is central to both research in strategic management and innovation policy making (e.g., Katila and Ahuja, 2002; Laursen and Salter, 2006; Edler and Polt, 2008). Many firms incorporate knowledge from external sources such as universities to enhance their innovation performance. The performance effects stem from new products based on novel combinations of internal and external knowledge (Rosenkopf and Nerkar, 2001) or more efficient R\&D processes (Fleming and Sorenson, 2004). However, our current theoretical understanding of how firms should organize their search for external knowledge is fragmented. One stream of research envisions knowledge search as relational in nature. Connecting with external partners “requires extensive effort and time to build up an understanding of the norms, habits, and routines of different external knowledge channels” (Laursen and Salter, 2006: 135). In other words, the use of external knowledge requires the presence of idiosyncratic linkages if the firm is to reap relational rents (Dyer and Singh, 1998; Dyer and Hatch, 2006). A second prominent, but largely unconnected stream of literature characterizes the search for knowledge as transactional. Search occurs in markets for technology ${ }^{1}$ on which disembodied knowledge is traded at a certain price (Arora, Fosfuri, and Gambardella, 2001; Arora and Gambardella, 2010; Arora and Nandkumar, 2012; Agrawal et al., 2015).

We observe many firms to adopt both relational and transactional search strategies at the same time: they may collaborate intensively with university scientists in a joint research project while licensing in technology from a specialized supplier. While following any of those strategies increases the openness of a firm to external knowledge in its innovation process, the open innovation literature (Chesbrough, 2003)

\footnotetext{
${ }^{1}$ Other studies use the term “markets for ideas” (Gans and Stern, 2003, 2010; Agrawal, Cockburn, and Zhang, 2015) for the market-based exchange of knowledge. However, we find no theoretical discrepancy between that term and the term "markets for technology" within the framework of our study, and we believe that the latter reflects a closer link with recent strategic management literature (Arora and Nandkumar, 2012). Notably, this conceptualization is limited to the exchange of technological knowledge - it does not include the buying and selling of high-tech equipment, which would be governed by product markets (Conti, Gambardella, and Novelli, 2013).
} 
has yet to provide a consistent explanation for how these strategies are related to one another. Relational search provides firms with unique knowledge that will be difficult for competitors to imitate.

Transactional search and adopting more generic solutions, though, dilutes such uniqueness and threatens a firm's ability to appropriate value in downstream product markets. Hence, the goal of our article is to explain why firms engage in both relational and transactional knowledge search simultaneously. For this purpose we provide a theoretical logic and empirical test for why (a) relational and transactional knowledge search do not follow identical, interchangeable mechanisms in how they increase innovation performance and (b) that these effects on performance are not independent from one another. Put differently, we provide a rationale for why firms should engage in costly collaborations with selective partners even when knowledge can be acquired efficiently from markets for technology. Hence, we theorize on interrelated and complementary performance effects from relational and transactional search, i.e. adopting one search strategy has a higher marginal return on innovation performance when the other one is present as well.

We demonstrate the usefulness of our complementarity reasoning by exploring two contingency arguments, highlighting conditions under which complementarity is more likely to emerge: a firm’s distance to the technological frontier in its industry and the thickness of the market for technology. First, the closer a firm is to the technological frontier, the more unlikely it becomes that the firm can benefit from markets for technology because existing knowledge is unlikely to support frontier research. Instead, relational search offers potentials to co-create novel knowledge which can extend the technological frontier. Hence, we predict that the benefits from complementarity are likely to be higher if firms are increasingly distant from the technological frontier. Second, as market thickness, defined as the presence of enough potential buyers and suppliers to allow the market to match them efficiently (Roth, 2007; Gans and Stern, 2010), in an industry increases, the cost advantages and the flexibility associated with market transactions outweigh the advantages of relational search. Put differently, if large parts of the knowledge production in an industry are accessible through markets, building up costly relationships would become 
increasingly inefficient. Therefore, we predict that the benefits from complementarity are higher if markets for technology are shallow.

Overall, we make four contributions to the extant research. First, we eliminate a source of bias found in studies that investigate relational search while neglecting interactions with markets for technology (e.g., Laursen and Salter, 2006, Leiponen and Helfat, 2010). Our findings allow us to distinguish between general industry effects, such as technological opportunity or IPR regimes, and the influence of the market for technology. In so doing, we more clearly define a route for developing new theory on the complementarity between different channels of external knowledge acquisition. Moreover, we introduce a new direction in the theory on markets for technology. Several studies highlight the fact that markets for technology are underdeveloped or inefficient (Gans, Hsu, and Stern, 2008; Gans and Stern, 2010). However, mitigating mechanisms at the firm level have thus far been absent from theoretical development. We show that relational and market mechanisms are not isolated, and that adopting both relational and transactional search is especially valuable when markets for technology are underdeveloped. This highlights a promising avenue for future studies on markets for technology, which allow firms to adjust firm-level strategies to counterbalance weaknesses in market institutions.

Second, by focusing on the conditions for complementarity, our research clarifies a central tenet in resource- and knowledge-based theories, which maintain that firm-specific knowledge that results from relational search generally has the greatest potential to create competitive advantage (Kogut and Zander, 1992; Grant, 1996; Wang, He, and Mahoney, 2009). The firm-specificity of knowledge has been argued to complicate imitation by competitors and, thus, to slow diffusion, which in turn allows the firm to appropriate returns from innovation in downstream product markets (Helfat, 1994). However, firmspecificity in itself may be of little value if thick markets for technology facilitate competitors' access to substitute knowledge. As a consequence, firm-specificity becomes less effective as an isolating mechanism. We therefore need more nuanced theorizing on how firm-specific knowledge translates into competitive advantage (Wang et al., 2009). 
Third, we contribute empirically by introducing a novel measure that captures the thickness of the market for technology in monetary terms that are comparable across industries. Based on data from the German part of the European Community Innovation Survey (CIS), which includes 3,921 firm-year observations made from 2001 to 2009, we calculate and project aggregate firm expenditures on markets for technology in 20 different industries over time. The data provide us with a unique opportunity to capture the market for technology—at least for firms based in Germany—and thereby complement prior efforts in the literature that have focused on measures such as the supply of university patents (e.g., Arora and Nandkumar, 2012), or were limited to industries with high patent propensity (e.g., Gambardella, Giuri, and Luzzi, 2007). In this regard, our ability to provide aggregate expenditure figures remedies the general shortage of data on licensing and external R\&D contracting and may trigger future research on a variety of related topics (Agrawal et al., 2015). What is more, our empirical design allows us to disentangle what a firm has acquired from markets for technology (transactional search) from what was available on the market. Our measurement is informed by a series of semi-structured interviews with innovation executives managing the organization of external knowledge acquisition. These conversations also helped us gain a better understanding of how relational and transactional search interact and when engaging in both is particularly (or less) beneficial.

Fourth, our findings have direct implications for management practice as well as policy making. We provide more precise insights into how firms can benefit from open-innovation trends which go beyond generic recommendations on how firms should organize the search for external knowledge (Huston and Sakkab, 2006). At the same time, our findings can inform policy making. Several factors underlying the efficiency and coverage of markets for technology are subject to rules and regulations set by governments, such as regulations on IPR. Our findings indicate that changes in these rules have repercussions for firms that have developed relational search strategies. A comprehensive impact analysis of policy changes must include consideration of the fact that such firms will lose competitive advantage originating from specific knowledge ties if markets for technology are made more efficient. 


\section{THEORY AND HYPOTHESES}

In the following, we review the mechanisms underlying the relationship between relational and transactional knowledge search and innovation performance. We adopt a strategy definition of innovation performance as the economic returns of a firm from its innovations (e.g., Laursen and Salter, 2006; Nerkar and Shane, 2007). While prior literature has already established a positive association of both types of search in isolation with innovation performance (e.g., Laursen and Salter, 2006; Arora and Gambardella, 2010), theoretical predictions on the complementarity of relational and transactional search are novel to our model.

A precise definition of complementarity is crucial for our theoretical and empirical model. We follow Milgrom and Roberts (1990) and identify complementarity based on marginal performance effects of one activity when the other is present. Within our setting, relational and transactional search are complementary when the marginal return from engaging in relational search increases with engagement in transactional search and vice-versa. This approach has a long tradition in research on complementarity of knowledge-based strategies, for example on the complementarity of internal and external R\&D (Cassiman and Veugelers, 2006), buying and selling of R\&D outcomes and services (Cassiman and Valentini, 2016), exporting and product innovation in SMEs (Golovko and Valentini, 2011) or external R\&D and collaboration (Arvanitis et al., 2015). We will review literature on relational and transactional search respectively before combining both theory streams to identify complementarities.

In general, there are two mechanisms through which firms benefit from external knowledge. First, a firm that only conducts internal R\&D and reuses its internal knowledge stock might reach the limits of feasible re-combinations. In this regard, collaboration with external partners and the integration of external knowledge with internal knowledge has significant potential to increase the degree of novelty of a firm's knowledge and, consequently, its innovation performance (Rosenkopf and Nerkar, 2001; Katila and Ahuja, 2002). Second, external knowledge, especially knowledge gained from academic research, can 
guide the firm's R\&D activities towards promising outcomes. As a result, the firm’s internal time and resource requirements are likely to be comparatively lower (Fleming and Sorenson, 2004; Leone and Reichstein, 2012).

Relational and transactional knowledge search differ fundamentally from each other. For relational search firms establish a governance mechanism. Firms use collaborative agreements to establish preferred or exclusive access to knowledge sources outside the firm’s boundaries (Dyer and Hatch, 2006).

Collaborations are specific to a particular firm in the sense that a firm engages with selected partners, and it tailors knowledge identification and transfer to the particular norms and conventions of its various collaboration partners (Laursen, 2012). Relational search thus allows firms to create innovative products and services that cannot be immediately imitated by competitors (Helfat, 1994). Collaborations allow firms to co-develop knowledge with partners so that the results fit their particular needs. As a consequence, firms that engage in relational search are more likely to have unique offerings based on novel knowledge and to increase the downstream positive effect on appropriation in product markets.

However, given that investments in developing channels with a particular knowledge source are typically specific to that source, such as the co-location of laboratories with a university, the firm's search becomes path-dependent and loses flexibility because a change in the search strategy would be costly. Opportunities for comparing alternative technological solutions are limited. Moreover, the focal firm has to cover all costs of relational search. These costs can be so substantial that they outweigh the potential benefits of relational search (Laursen and Salter, 2006).

In contrast, transactional search occurs on markets for technology through external R\&D contracting or in-licensing (Cassiman and Veugelers, 2006; Cassiman and Valentini, 2016). These markets organize the transfer of knowledge at certain prices and in a disembodied form (Arora et al., 2001; Conti et al., 2013). In principle, the market for technology is separate from the acquisition of equipment or the hiring of new employees, and the acquired knowledge should be ready to be used by the buyer. The knowledge must, 
therefore, be comprehensively codified so that the buyer can use it without further interaction with its producer. $^{2}$

It is important that enough potential buyers and suppliers are present to allow the market to match them efficiently (“thickness of the market”) (Roth, 2007; Gans and Stern, 2010). In this context, knowledge exchange does not depend upon the presence of a specific knowledge buyer-supplier dyad, and the value of the knowledge is only indirectly determined by individual market participants. On perfectly efficient (i.e., thick, uncongested, and safe) markets for technology, potential buyers and suppliers can reveal their preference prices for a particular technology, and the market mechanism determines the equilibrium price at which buyers and suppliers cannot find a better offer. Efficient markets allow for allocative efficiency (Arora and Gambardella, 2010). However, many market transactions do not emerge in such clear-cut form. They can be embedded, e.g. in alliance agreements ${ }^{3}$ (Arora et al., 2001), or reduce the search costs borne by buyers and suppliers of knowledge by providing more limited services, such as brokerage, auctioning, or online presentation (Yanagisawa and Guellec, 2009; Dushnitsky and Klueter, 2011). At the same time, the types of knowledge that can be traded on markets for technology are limited, as the knowledge must typically be fully developed, codified, and ready to use.

Markets allow knowledge producers to sell the knowledge itself instead of developing complementary assets in, for example, distribution, manufacturing, or servicing for the purpose of commercializing that knowledge on the product market (Lamoreaux and Sokoloff, 2001; Gans and Stern, 2003). Conversely,

\footnotetext{
${ }^{2}$ We acknowledge that research has found that firms can increase the benefits that they can generate from licensed technologies when they involve the individual that invented a technology (Agrawal, 2006). For our arguments, it is important to note that such involvement is not a necessary condition to benefit from the acquired knowledge.

${ }^{3}$ Firms may collaborate and at the same time in-license technology from that collaboration partner which may raise concerns whether relational and transactional search can be accurately separated. This would be unproblematic if the collaboration and the in-licensing agreement concerned different technologies or knowledge elements. It would be more problematic if it concerned the same technologies or knowledge elements. An example could be that the outcome of collaborative research is patented by only one partner while the other partner receives an exclusive license. Anecdotal evidence suggests ex-post licensing to be widespread. However, such ex-post in-licensing is unlikely to incur royalty payments, which is confirmed by several of our interview partners, while our measurement of transactional search is based on actual expenditures.
} 
firms that possess complementary assets do not need to invest in the development of new technologies because they can simply buy them on the market for technology (Arora and Nandkumar, 2012). Arora and Nandkumar (2012), however, caution that the value of acquired or in-licensed knowledge may be lower for the firm because the uniqueness of the knowledge is reduced; in principle, the same knowledge is also available to competitors. Table 1 summarizes the comparison between relational and transactional search.

[Table 1 about here]

\section{Sources of complementarity between relational and transactional search}

Our arguments for complementarity of relational and transactional search are grounded in two lines of reasoning. On the one hand, firms can overcome disadvantages from transactional search (i.e. inefficient markets for technology) and relational search (i.e. partner-specific investments) by combining them. On the other hand, firms can use scarce absorptive capacities for identifying, assimilating and exploiting external knowledge more efficiently through a combination of relational and transactional search. We develop both lines of reasoning.

First, firms engaging in relational and transactional search simultaneously can alleviate the weaknesses of each individual search type. Particularly markets for technologies have been criticized for being inefficient. In the absence of sufficient buyers and suppliers (thickness) as well as safe and frictionless (uncongested) market transactions, the benefits of transactional search are unlikely to emerge. Agrawal et al. (2015) show that firms are less likely to find potential partners on markets for technology lacking thickness, fail to initiate negotiations on congested markets and cannot close sales agreements if IPRs cannot be safely transferred. Under such conditions, firms are better off complementing transactional search with relational search. Within relational search, firms form partnerships with selected partners. Partnerships rely on social mechanisms to balance the potential hazards from relying on inefficient market transactions (Poppo and Zenger, 2002; Bäck and Kohtamäki, 2016). These social mechanisms rely on the assumption that partners can derive long-term benefits from establishing reputation and trustworthiness 
(Greif, 1989, 1993). Cooperative behavior in partnerships emerges because the expected payoffs from a partnership in the future are high enough to incentivize cooperative behavior of all partners in the present (Baker, Gibbons, and Murphy, 2002). Accordingly, a partner in relational search can build a reputation for trustworthiness in the future by abstaining from opportunistic behavior in the present. The result is a partnership characterized by information sharing, flexibility and solidarity which is long-term oriented (Poppo and Zenger, 2002). Such reputation effects from relational search have the potential to be transferred to transactional search. Sellers on markets for technology that lack thickness, are congested or have deficits in the safety of transactions, are likely to prefer dealing with buyers which have a demonstrated reputation for trustworthiness. In sum, relational search can provide access to external knowledge which could not have been accessed safely and without frictions on inefficient markets for technology.

Conversely, engaging in transactional search can also improve the performance effects of relational search. Firms engaging in relational search are likely to make specific investments with particular partners, e.g. converging towards joint templates or procedures (Laursen and Salter, 2006). Such partnerspecific investments make the transfer of knowledge more effective and efficient. Then again, the positive effects of relational search can reach their limits, particularly in repeated partnerships. Holloway and Parmigiani (2016) show that repeated partnerships increase the risks from opportunistic behavior due to increased dependence, lower incentives to realize efficiency gains in the partnerships and overlooking superior technological options. A firm that complements relational search with transactional search is less likely to experience these downsides. The awareness of the knowledge available on markets for technology reduces the dependence on particular partners from relational search and provides it with a broader view of ongoing technology development outside of any particular partnerships. Hence, the risks from overlooking technological trends are reduced. As a consequence, transactional search increases the marginal effect of relational search on innovation performance. 
Second, a separate mechanism for the complementarity of relational and transactional search can be found in a firm's capacity to absorb external knowledge. We argue that a combination of relational and transactional search uses a firm's absorptive capacities more efficiently than any one in isolation. We base this argument on the particular nature of relational search. While relational search has the potential to provide firms with unique knowledge which is not available to competitors and often times co-created or tailored to their needs, it also requires substantial partner-specific investments to absorb the knowledge. Absorptive capacities are a scarce resource within firms because they emerge from firms' internal R\&D investments in the past (Cohen and Levinthal, 1989). Research on relational search has found that firms experience negative performance effects when they extend their search over too many different partners (Laursen and Salter, 2006). Relational search is particularly costly because firms engage deeply and specifically with particular partners. They develop a shared language and shared procedures with those partners (Laursen and Salter, 2006). Once a firm reaches the limits of its absorptive capacity for relational search, the average effect on innovation performance decreases because knowledge is no longer sufficiently screened and evaluated resulting in forgone opportunities or erroneous choices (Koput, 1997).

Firms can reduce the demands on absorptive capacity from their relational search when they combine it with transactional search. Markets for technology provide knowledge sources with high powered incentives to offer their knowledge (Felin and Zenger, 2014). Hence, fewer absorptive capacities of a searching firm are required for identifying promising knowledge sources. What is more, the knowledge on markets for technology is necessarily codified and disembodied from the knowledge producer (Conti et al., 2013). In such a format the external knowledge is unlikely to require substantial transformation before it can be combined with the firm's existing knowledge stock. Such transformation can be a substantial cost factor in the absorption of external knowledge (Todorova and Durisin, 2007). In sum, the absorptive capacity requirements for the absorption of external knowledge from transactional search are comparatively lower than from relational search. Therefore, firms can free up scarce absorptive capacities 
through transactional search and shift them to relational search. Such a combination will increase innovation performance.

In fact, a senior manager for new product planning at a multinational pharmaceuticals firm underlined that relational and transactional search reinforce each other:

We do both [collaboration and in-licensing] and I suspect that most firms in our industry do. When we need to do basic research in a project we collaborate with a university hospital that works in a field we are interested in. At the same time, we look for technologies that would benefit the project and that we could license in.

In sum, we propose:

Hypothesis 1: Relational and transactional search are complementary in their effect on innovation performance.

\section{Heterogeneity in complementarity effects between relational and transactional search}

Based on the mechanisms laid out for Hypothesis 1 we explore to what degree the complementarity effects are particularly strong in certain contexts. For this purpose we choose a contingency at the firm level, i.e. how close the searching firms is to the technological frontier, as well as a contingency at the industry level, i.e. how thick the market for technology is in a particular industry. We start out by discussing the strength of the complementarity effect between relational and transactional search when firms are close or further away from the technological frontier.

The concept of a technological frontier is typically a regional one in which firms in a country (Mahmood and Rufin, 2005) or even worldwide (Kumar and Russell, 2002) can be ordered based on how technologically advanced they are. The frontier itself is the hypothetical constraint on the maximum of 
technological opportunity at a given point in time (McCain, 1977). Given this standard, firms can be leading or lagging relative to the average firm, i.e. be closer or more distant to the frontier. For the purpose of our reasoning it is important that this relative position changes the degree to which they experience complementarity effects from relational and transactional search.

Extant literature has found that the relative position of a firm to the technological frontier affects how firms access and process knowledge. Some studies associate technological leadership with scale (Henderson and Cockburn, 1996) and experience effects (Sinclair, Klepper, and Cohen, 2000) from reaching the frontier which allows leading firms to absorb new knowledge more effectively. Similarly, Salomon and Jin (2010) find that leading and lagging firms benefit from exposure to export markets but that the increase in innovation performance of leading firms is stronger. Mahmood and Rufin (2005) describe how the search for knowledge differs between firms operating close to the technological frontier compared with firms which are lagging further behind. Firms close to the frontier are more likely to experience that they search for knowledge which does not yet exist. Hence, they are forced to draw on diverse sets of external knowledge sources and develop new knowledge. Lagging firms experience knowledge search in a different way (Mahmood and Rufin, 2005). For them the search field is much narrower and the search direction much more predictable because they are not the first ones to require new knowledge. Lagging firms are comparatively less likely to require unique, external knowledge. They can imitate leading firms.

We have laid out two mechanisms for complementarity effects between relational and transactional search in our reasoning for Hypothesis 1. These are the opportunities for firms to mitigate the weaknesses of transactional search (inefficient markets for technology) and relational search (partner-specific investments) as well as the more efficient use of scarce absorptive capacities when firms combine both types of search. While both leading and lagging firms may benefit from engaging in relational and transactional knowledge search, we expect lagging firms to be comparatively more likely to experience complementarity effects. Lagging firms are more likely to search in a search space in which solutions are 
already fully developed. Leading firms have explored this search space before and have made it more predictable for all lagging firms (Mahmood and Rufin, 2005). This increases the odds that suitable solutions are available on markets for technology. Hence, lagging firms are comparatively more likely to have opportunities from transactional search. They have more opportunities to use transactional search for avoiding the negative effects from repeated partnerships and specific investments in relational search (dependence, lack of incentives for efficiency gains, overlooking alternative technological options) (Holloway and Parmigiani, 2016). Besides, lagging firms are comparatively more likely to free up scarce absorptive capacities for relational search with particularly promising partners since they have comparatively more opportunities to use markets for technology. As a result, the marginal performance effect of relational search in the presence of transactional search is higher for firms which are further away from the technological frontier. Consequently, the latter firms are comparatively more likely to experience complementarity effects between relational and transactional search.

In contrast, the frontier nature of the knowledge search of leading firms requires them to develop knowledge in collaboration with external partners because no finished solutions exist on markets. Hence, relational and transactional search are largely isolated from one another for leading firms. Both may be beneficial but one is less likely to increase the marginal performance effect of the other. This reasoning is confirmed by a general manager of the industrial textiles division of a large industrial conglomerate.

We like to see ourselves as an 'innovation champion'. Together with customers and research partners, we want to develop leading-edge technologies and products. We don’t do so much licensing because we don't want to have what our competitors have.

We hypothesize:

Hypothesis 2: The benefits from complementarity of relational and transactional search are greater if firms are more distant to the technological frontier in an industry. 
We consider the thickness of the market for technology in an industry as a second relevant context variable for the strength of complementarity effects between relational and transactional search. We have argued that the opportunities of firms to counter the downsides of inefficient markets for technology through relational search are a central aspect leading to complementarity. Agrawal et al. (2015) identify the thickness of markets for technology (or the absence thereof) as an important barrier to transactional search because it affects the early stages of potential deals in which buyers and sellers have not found one another for bilateral negotiations. The term “thickness” originates from the literature on market design (Roth, 2007; Gans and Stern, 2010). Thick markets offer buyers and sellers access to many potential trading partners (Agrawal et al., 2015). We use the term "shallow" to refer to markets with comparatively few transaction partners.

Industries differ in how thick their markets for technology are. Important determinants of market thickness are the nature of the knowledge that is tradable and the institutional rules, especially rules on IPRs, which govern potential market transactions. First, knowledge traded on markets needs to be codified. Although, in principle, all knowledge can be codified, the costs of doing so can be excessive (Conti et al., 2013). If the costs are too high, the knowledge will not be codified and therefore not offered on the market for technology. Second, appropriability regimes are determined by the legal and technological conditions in an industry (Teece, 1986). As appropriability hazards increase, fewer knowledge producers will be willing to offer knowledge on a market for technology (Gans et al., 2008). Arundel and Kabla (1998) estimate that roughly one-third of all inventions are patented. They find that this patent propensity ranges from 15 percent in iron and steel production to 74 percent in pharmaceuticals. Hence, there is a remarkable share of knowledge that is either kept secret (e.g., Hall et al., 2014) or that does not qualify for patenting based on the formal criteria of the patent office or inventors' expectations of benefits. The low levels of patented knowledge combined with significant inter-industry differences consequently affect the functioning of markets for technology. 
Thicker markets for technology affect the innovation performance potentials of both relational and transactional search. Market thickness has been found to be a particularly important factor in the early stages of licensing agreements, i.e. when sellers and buyers compare multiple potential partners and their knowledge (Agrawal et al., 2015). Hence, thicker markets for technology provide richer and broader opportunities for licensing. Thick markets for technology increase the comparative disadvantages of relational search. The presence of a thick market for technology enables firms to test and adjust technological solutions flexibly. Hence, the consequences of missing out on promising technologies or making wrong choices are limited. In contrast, relational search requires that firms engage deeply with particular partners, develop shared norms and understandings which result in path dependence (Laursen and Salter, 2006). Given thick markets for technology, relational search is comparatively much more likely to lead to consequential lock-in effects in the particular technology of a chosen partner. This notion is reflected in the statement of the pharmaceuticals product manager.

When we have the opportunity, we often acquire external technology as a backup. This reduces the risk for us and we don’t have to co-develop everything with a research group at a university hospital.

Besides, relational search implies that firms bear all the costs for identifying and absorbing the knowledge from their collaboration partners. Thick markets, in contrast, provide strong incentives for knowledge producers to offer their knowledge proactively (Felin and Zenger, 2014). What is more, the market mechanism requires that the knowledge be offered in codified form and largely ready to use, i.e. not requiring further interaction with the knowledge producer (Conti et al., 2013). These features reduce absorption costs. The consequences of thick markets are illustrated by a senior consultant at a specialized energy consultancy that generally collaborates with customers on new products:

We had researched and developed a new forecasting model. Afterwards we discovered that existing algorithms in the market could be relatively easily 
adapted and this rendered our research effort futile. [...] We rely heavily on external suppliers and software houses for new algorithms and mathematical models.

In sum, we conclude that transactional search on thick markets for technology will provide more and better knowledge which can be acquired or in-licensed. As a consequence, risks from lock-in effects from partner-specific investments are reduced and limited absorptive capacities are freed up for more focused relational search. Under such conditions, firms are more likely to substitute relational with transactional search. The marginal increase in the performance effect of relational search from transactional search diminishes as markets for technology become thicker. Put differently, we conclude that thick markets for technology erode potential complementarity effects of relational and transactional search. Therefore, complementarity effects between relational and transactional search are comparatively more likely to emerge on shallow markets for technology. We predict:

Hypothesis 3: The benefits from complementarity of relational and transactional search are greater if firms operate in an industry with shallow markets for technology.

\section{DATA AND METHODS}

\section{Data}

Our empirical analysis relies on data from the "Mannheim Innovation Panel” (MIP), which is the German contribution to the European Union’s Community Innovation Survey (CIS). The methodology and questionnaire follow CIS standards and the so-called Oslo Manual of the OECD (OECD, 2005). The Oslo Manual contains detailed guidelines for the collection, measurement and analysis of innovation survey data. CIS surveys target decision makers responsible for firms' innovation activities, such as CEOs, and heads of innovation management units or R\&D departments in European Union member and associated countries. Respondents provide direct, importance-weighted answers to a number of questions on 
innovation inputs, processes, and outputs. Several recent contributions in the strategy and innovation literature have relied on data provided by CIS surveys (e.g., Cassiman and Veugelers, 2006; Laursen and Salter, 2006; Grimpe and Kaiser, 2010; Leiponen and Helfat, 2011; Klingebiel and Adner, 2015).

CIS surveys are subject to extensive pre-testing and piloting in various countries, industries, and firms with regards to interpretability, reliability, and validity (Laursen and Salter, 2006; Eurostat, 2009). Moreover, the questionnaire contains detailed definitions and examples to increase response accuracy. The German CIS has been undertaken annually since 1993 with a response rate of around 25 percent which is slightly lower than in other CIS countries (Cassiman and Veugelers, 2006; Laursen and Salter, 2006). However, it is one of only four national surveys that provides non-response analyses as an additional layer of quality, finding no evidence of any systematic distortions between responding and non-responding firms and thus providing an accurate representation of the population of German firms (Rammer et al., 2005). Nevertheless, there are differences in the share of innovating firms between responding and non-responding firms (Peters and Rammer, 2013).

Not all variables of interest are available on an annual basis and not all firms answer the questionnaire regularly. We use data from the surveys conducted in 2001, 2005, and 2009, all of which contain our variables of interest. The questionnaires refer to the three-year period prior to the survey year, i.e. to 1998-2000, 2002-2004, and 2006-2008, respectively. After removing observations lacking responses, we end up with an unbalanced panel of 3,921 firm-year observations, corresponding to 3,414 unique firms. ${ }^{4}$ We complement our dataset with patent statistics obtained from the PATSTAT database of the European Patent Office (EPO).

\footnotetext{
${ }^{4}$ Similar to other CIS-based studies (e.g., Leiponen and Helfat, 2011; Klingebiel and Adner, 2015), we are interested in the differences in product innovation performance among firms, which is why we restrict the sample to those firms engaged in product innovation. Prior research on the German CIS has shown that results are not biased due to the selection of innovative firms (Grimpe and Kaiser, 2010; Klingebiel and Adner, 2015). As a consequence, we exclude firms with knowledge searching activities that are unrelated to innovation activity (since the information used to measure relational and transactional search is only collected for firms with innovation activities).
} 


\section{Variables}

\section{Dependent variable.}

The extant literature features a variety of constructs used to measure innovation performance (for an overview, see OECD, 2005). These include innovation inputs, such as R\&D expenditure, and a broad range of output measures, such as patents, new processes, and products. Our research follows the latter approach. As the existence of a novel product is hardly a good predictor of the economic performance of an innovation, we focus on market acceptance, which turns a novelty into a successful product innovation. Consequently, we follow other CIS-based literature and use the sales of newly introduced product innovations as our measure of innovation performance (e.g., Leiponen and Helfat, 2011; Klingebiel and Adner, 2015). The variable measures sales in the last year of the three-year survey period (i.e. 2000, 2004, and 2008) of product innovations that were introduced during the three-year period. ${ }^{5}$ It contains raw values expressed in natural logarithmic terms which have greater construct validity compared with new product sales normalized by a firm’s total sales (Klingebiel and Adner, 2015). Such ratios complicate interpretation because an increase could either be due to the firm selling more new products or experiencing lower overall sales. Moreover, they could lead to extreme values for small firms. Still, we will check robustness of our results using ratios.

CIS surveys draw a distinction between sales of products new to the firm and sales of products new to the market, where the latter indicates a higher degree of novelty. We measure sales of products new to the firm. This measure includes products that are new to the market and is, therefore, the more comprehensive construct. Moreover, the correlation between the two figures is high (0.55).

\footnotetext{
${ }^{5}$ Consistent with the lag design of recent CIS studies (e.g., Cassiman and Valentini, 2016; Klingebiel and Adner, 2015), we relate innovation performance to the innovation activities in the preceding three years.
} 


\section{Focus variables.}

Following prior complementarity studies (Cassiman and Veugelers, 2006; Golovko and Valentini, 2011; Cassiman and Valentini, 2016), we characterize a firm's relational and transactional search with two dummy variables. For relational search, we make use of a survey question that asks firms whether they had engaged in innovation collaboration, defined in the questionnaire as "active participation in joint innovation projects or research projects with other enterprises and/or with non-commercial organizations such as universities or research institutes”. We believe that this question adequately measures relational search since firms need not only build up a relationship with a partner to initiate collaboration but potentially also invest into the capability to collaboratively undertake innovation or R\&D projects. ${ }^{6}$ In the questionnaire, firms could indicate whether they had such collaboration with suppliers, customers, competitors, consultants, universities, or public research institutes, and where these collaborators were located. Any incidence of collaboration leads to a value of one of the corresponding dummy variable (henceforth: COLLABORATE) and zero otherwise. Following Cassiman and Veugelers (2006) and Cassiman and Valentini (2016), we define a dummy variable representing transactional search that takes the value of one if the firm reports expenditures on either external R\&D contracting or in-licensing (henceforth: BUY) and zero otherwise. The questionnaire allows us to identify transactions which are directly related to innovation projects. This makes it less likely to include ex-post licensing fees, e.g. situations in which firms develop technologies independently but are forced to pay licensing fees because another firm received patent protection first, or licensing fees related to the technology use of a component supplier. In both cases licensing is unlikely to reflect knowledge search.

\footnotetext{
${ }^{6}$ Several studies have relied on patent statistics to measure search (e.g., Rosenkopf and Nerkar, 2001), but these statistics only reflect particular knowledge flows and sources. Moreover, patenting activity is concentrated, with relatively few sectors holding dominant shares of all patents (e.g., pharmaceuticals) (Arundel and Kabla, 1998). A significant proportion of inventions is not patented because of cost and disclosure considerations, or because they do not qualify for patent protection (e.g., Griliches, 1979; Encaoua, Guellec, and Martinez, 2006). In sum, the knowledge a firm may search for is likely to be much more diverse than the patented sub-domain.
} 
Although we adopt standard practice in the literature on complementarities in innovation strategies, using two dummy variables to characterize the two search strategies may seem coarse since firms may vary in the extent to which they make use of relational and transactional search. Our measurement corresponds to the argument implicit in our hypotheses that relational and transactional search reflect the adoption of distinct organizational choices (Cassiman and Valentini, 2016). We will return to this issue in the discussion of our results.

To test the two contingency hypotheses, we define two dummy variables that serve to split the sample accordingly. Technology leadership is defined as a dummy variable that takes the value of one if a firm has higher expenditure on $R \& D$, relative to its sales, than firms have on average in the NACE two-digit industry of the focal firm (Salomon and Jin, 2010) and zero otherwise. ${ }^{7}$

To measure the thickness of the market for technology in an industry, prior literature has focused on narrow sets of high-tech industries (Gans et al., 2008) and high patent propensity (Gambardella et al., 2007) or relied on university patents as a measure of supply on markets for technology (Arora and Nandkumar, 2012). However, these measures capture only a fraction of the actual market for technology available to firms. Therefore, we rely on a novel measure that we believe more appropriately reflects the availability of knowledge on markets for technology. Since the German CIS is a representative dataset based on stratified random sampling of the complete population of German firms, projected figures on innovation expenditures can be calculated for the entire population on the NACE two-digit industry level. ${ }^{8}$ We use these figures on firms' external R\&D and in-licensing expenditures, normalized by the

\footnotetext{
${ }^{7}$ It has to be noted, though, that this measure of technology leadership is rather coarse as above average R\&D intensity at the two-digit industry level may simply represent a firm's specialization on a different market segment which requires higher R\&D input than other market segments in the same two-digit industry.

${ }^{8}$ The projected figures were calculated by the Centre for European Economics Research (ZEW) which administers the German CIS. They constitute the official reporting by the German Federal Ministry of Education and Research.
} 
total industry innovation expenditures, as our measure of the thickness of the market for technology. ${ }^{9}$ The measure captures the equilibrium expenditure for external R\&D and licensed technology among German firms (showing both the supply and the demand conditions in the industry) and thus the relative importance of the market for technology in an industry compared to other means of knowledge production like internal $R \& D$ and related expenditures. In other words, the measure captures to what extent the market for technology covers the production of knowledge relevant for innovation in an industry. The two-digit industry classification allows us to identify relevant markets that are neither too narrow nor too broad. We obtain 20 different markets for technology per observation period in which, for example, automobile manufacturers are in the same industry group as suppliers of automotive parts. We adjust the industry measures by subtracting the focal firm's own respective expenditures. Finally, we define a dummy variable that takes the value of one if firms are active in an industry with above median thickness of the market for technology and zero otherwise.

Nevertheless, the measure is limited to the extent that it only captures the market for technology for German firms and German subsidiaries of foreign firms which may have sourced their technology both within Germany and abroad. It does not account for the expenditures of firms outside Germany. We therefore search for alternative sources of data to check the validity of our measure. Prior research contains numerous estimations of the (worldwide) size of the market for technology. Arora and Gambardella (2010), for example, argue that its size has more than tripled between 1995 and 2002 in terms of transaction value, reaching about \$100billion. Focusing on the supply side, Robbins (2006) estimates the total income from licensing in the United States in 2002 to be about \$50billion. These estimates, however, typically do not disaggregate the market size per industry or they are only focused on

\footnotetext{
${ }^{9}$ For CIS purposes, innovation expenditures are defined as the sum of expenditures for internal and external R\&D, for machinery, facilities and software procured in the context of innovation projects, for in-licensing, for training and qualification measures in the context of innovation projects, for the market launch of innovations, and for product design, service and the distribution of innovations.
} 
single industries like pharmaceuticals. The OECD provides a potential source of data to validate our measure in the Technology Balance of Payments (OECD, 2009). It collects receipts and payments for international technology transfers, including license fees, patents, purchases and royalties paid, knowhow, research and technical assistance. For Germany, data are available only for two-digit manufacturing industries but they allow correlating the numerator of our measure with the OECD figures. Correlations turn out to be very high $(0.85,0.88$, and 0.89 , for the three survey years) which makes us confident that the projected data from the German CIS actually cover the market for technology by industry.

As a robustness check, we define two alternative measures for the thickness of the market for technology: first, we divide the industry’s expenditure for external R\&D and licensed technology by the total industry sales instead of the total innovation expenditures. We regard this measure as less useful, however, as it does not reflect an industry’s overall orientation towards innovation but only its overall size. Second, we exclude external $R \& D$ expenditures from the numerator since external $R \& D$ expenditure could potentially also include payments made during the course of collaborative projects.

\section{Control variables.}

Several other factors have been identified in the literature as influencing a firm's innovation performance (for an extensive review see Ahuja, Lampert, and Tandon, 2008). Of these, we include the firm's R\&D intensity, defined as the firm's internal R\&D expenditure relative to sales. To account for differences in firms’ past R\&D activities, we calculate the patent stock for each firm based on all patents filed at the European Patent Office from 1978 to $t$-2 of the survey year using the perpetual inventory method with a constant knowledge-depreciation rate of 15 percent, which is standard in the literature (e.g., Hall, Jaffe, and Trajtenberg, 2005). As this variable is highly skewed, we normalize it by the firm's number of employees. Moreover, we include the firm's size in terms of the number of employees (in log), whether the firm is part of a company group (dummy), and whether it engages in process innovation (dummy). All of these factors have been found to influence a firm's knowledge-production function (Grimpe and 
Kaiser, 2010; Klingebiel and Adner, 2015). We control for the degree of internationalization using the share of exports relative to total sales because internationalization and innovation activities are related (Cassiman and Golovko, 2011). Following Leiponen and Helfat (2011), the models also include a measure of past performance to account for unobserved heterogeneity among firms and potential reverse causality such that good or bad past performance may lead firms to adopt a certain search strategy. Specifically, we use past labor productivity of the firm defined as total sales divided by the number of employees from $t$-2 (i.e., 1998, 2002, and 2006). Finally, we include 19 industry dummies at the NACE two-digit level to control for any remaining industry effects, and we include survey-year dummies.

\section{Model}

Since testing for complementarity is an econometrically challenging task (Athey and Stern, 1998), we follow the estimation strategy employed in prior literature (e.g., Cassiman and Veugelers, 2006; Golovko and Valentini, 2011; Cassiman and Valentini, 2016). We start by regressing innovation performance on the two search strategies and our set of control variables. The test for complementarity requires that the dummy variables be expressed in exclusive terms, leading to four variables: (1) No COLLABORATE no BUY, (2) Only COLLABORATE, (3) Only BUY, (4) COLLABORATE and BUY. The two search strategies are complementary if the following equation holds:

\footnotetext{
Performance (COLLABORATE and BUY) - Performance (Only COLLABORATE) $\geq$ Performance (Only BUY) - Performance (No COLLABORATE no BUY)
}

Hypotheses 2 and 3 are then tested by splitting the sample along the two dummy variables for technology leadership and thickness of the market for technology. We expect complementarity of relational and transactional search to be greater when firms are not technology leaders (Hypothesis 2) and when they operate in shallow markets for technology (Hypothesis 3). The split-sample regressions also include the respective variable used to create the group dummy, i.e. firm $R \& D$ intensity less the industry $R \& D$ intensity and the thickness of the market for technology. Since for a number of observations our 
dependent variable, the sales with new products, contains a zero, we estimate random-effects Tobit models (Wooldridge, 2007). ${ }^{10}$

We employ several sets of models to refine our search for complementarity and to check for consistency and robustness of our results. These models are presented and discussed in the appendix. First, we estimate our main models using pooled (with Huber-White standard errors clustered by firm) Tobit and OLS regression models to check whether our results are sensitive to a different type of estimation model. Second, following Cassiman and Veugelers (2006), the test of hypotheses 2 and 3 is refined by means of bivariate probit and multinomial probit models to further examine the drivers of the combinations of relational and transactional search. We also estimate OLS models predicting the four possible combinations of search strategies. Third, we run a series of estimations using alternative measures in the regression, such as a different definition of market thickness, a different dependent variable that captures the firm's sales with products new to the market, as well as an expression of the dependent variable as a ratio by dividing new product sales by the firm’s total sales.

Since we are limited in the extent to which we can exploit the panel structure of our data, we need to pay close attention to potential issues arising from endogeneity, which we address in a number of ways. First, our models include a measure of past performance which can be interpreted as a dynamic fixed effect in order to account for unobserved heterogeneity among firms and potential reverse causality. Specifically, more successful firms may be more likely to collaborate because they are perceived as attractive collaboration partners. Second, the multinomial probit models provide an additional opportunity to check

\footnotetext{
${ }^{10}$ We use a random-effects model instead of a fixed-effects model for several reasons. First, fixed-effects models cannot incorporate time-invariant covariates. While the binary variables measuring the adoption of the two search strategies can vary, they do not vary in practice for many observations in the sample because firms that collaborate in one year also choose to do so in subsequent years. Using fixed effects would thus artificially restrict the sample. Second, random-effects estimates are typically more efficient for panels over short periods like ours of essentially only three years of observations. Third, when samples are drawn from a large population, such as in our case, viewing individual-specific constant terms as randomly distributed across cross-sectional units is more appropriate. Apart from this, Tobit models are non-linear and thus the likelihood estimator for fixed effects is biased and inconsistent (Wooldridge, 2007).
} 
whether past performance drives the adoption of search strategies. Third, we use the multinomial probit models as a way to correct for endogeneity of the search strategies in the innovation performance models by calculating predicted probabilities and using those as instrumental variables in the performance regressions (see section (4) of the appendix).

\section{RESULTS}

Table 2 shows frequencies and average innovation performance for the four search strategies. We find that not engaging in relational or transactional search is the most frequently chosen strategy, followed by the joint adoption of relational and transactional search. Most importantly, there is a sufficient number of firms in each cell (i.e. also for exclusive relational and transactional search, respectively) to ensure reliability of the complementarity test. Firms jointly adopting relational and transactional search clearly show the highest innovation performance in terms of sales with new products. Since this may be considerably driven by firm size, we report the share of sales with new products which also turns out to be highest for joint adopters. These findings provide a first descriptive indication of complementarity between relational and transactional search.

[Table 2 about here]

Table 3 provides summary statistics for the full sample as well as for firms engaged in relational and transactional search, respectively. Firms that engage in relational or transactional search have on average about twice as high innovation sales compared to all firms in the sample. However, this is also very much driven by firm size as the average number of employees in the samples indicates. Firms do not vary much in terms of their past performance (i.e. labor productivity) and their patent stock. Firms which adopted either one of the search strategies, though, show on average higher R\&D intensity, export intensity, engagement in process innovation as well as likelihood of being part of a group of firms.

[Table 3 about here] 
Table 4 shows the pairwise correlation coefficients. The mean variance inflation factor (including all industry and survey year dummies) equals 1.48 and the condition number is 14.09 , which, together with the low correlations among the explanatory variables, suggests that the data do not suffer from collinearity problems (e.g., Belsley, Kuh, and Welsh, 1980).

[Table 4 about here]

Table 5 shows the results of the main random-effects Tobit regression models. Model 1 shows the results of the controls-only baseline specification. As expected, we find positive and significant relationships between all control variables and innovation performance. These findings are in line with prior studies in the field that use a similar production function approach (e.g., Laursen and Salter, 2006; Grimpe and Sofka, 2009; Grimpe and Kaiser, 2010). Moreover, the 19 industry dummies are jointly significantly different from zero, while the survey-year dummies are not. Model 2 contains the three mutually exclusive dummy variables measuring a firm’s adoption of search strategy. The reference category is the non-adoption of either search strategy. ${ }^{11}$ It turns out that only the joint adoption of relational and transactional search is positively and significantly associated with innovation performance; following only one of the two search strategies in isolation does not seem to pay off. We can substantiate complementarity if the parameter estimates for the joint adoption are equal to or larger than the sum of the parameter estimates for the adoption of each search strategy in isolation. We find evidence of complementarity, even though only on the $10 \%$ level of significance, which provides support for Hypothesis $1 .^{12}$

\footnotetext{
${ }^{11}$ The results are conceptually and computationally the same if the reference category is included and the model estimated without the constant term.

12 To provide further evidence of complementarity, we use the non-exclusive dummy variables for relational and transactional search as well as their multiplicative interaction. We find a positive and significant relationship with innovation performance for both variables. The interaction effect turns out to be positive and significant, which is suggestive of complementarity. Moreover, we estimate a bivariate probit model to test for the joint adoption of the two strategies. If they are complementary one would
} 
Next, we turn to Hypotheses 2 and 3 and perform the same test on split samples that distinguish between technology leaders and laggards, and firms operating in thick and shallow markets for technology. Models 3 to 6 in Table 5 show the results. Consistent with our hypotheses, we find complementarity between relational and transactional search only in the sample containing technologically lagging firms, i.e. those that have lower R\&D intensity than the industry average, and in the sample in which firms operate in shallow markets for technology, i.e. in industries where the market for technology covers only a small fraction of the total innovation-relevant expenditures. The two variables that were used to define the split samples and which are now included in the regressions turn out to be largely insignificant while the estimation results for the remaining control variables are consistent with the main model.

\section{[Table 5 about here]}

As outlined before, we conduct a number of additional analyses and robustness checks to probe deeper into the complementary relationship between relational and transactional search. The results are presented and discussed in the appendix. They provide support for our hypotheses in the full and in the two split samples. Moreover, our results are robust to controlling for potential endogeneity of the search strategy adopted. Therefore, although we cannot fully rule out endogeneity issues due to the nature of our data, they are unlikely to influence the main findings.

As part of the consistency checks we estimate multinomial probit models for the choice of search strategy. This particular complementarity test assumes that ceteris paribus managers would always choose two complementary activities simultaneously and that the presence of efficient market mechanisms eliminates sub-optimal choices (Cassiman and Valentini, 2016). Hence, in contrast with other complementarity tests there is no direct link with performance. Table 7 of the Appendix shows the results. 
We find additional, significant support for Hypothesis 3 (shallow markets) but not for Hypothesis 2 (technologically lagging firms).

\section{DISCUSSION}

In this article, we theorize on the complementarity effects between relational and transactional search for knowledge. More precisely, we make predictions on how the marginal performance effect of one search strategy changes when the other is present. We base our reasoning for positive complementarity effects on two primary pillars. On the one hand, firms can overcome disadvantages from transactional (i.e. inefficient markets for technology) and relational search (i.e. partner specific investments) by combining them. On the other hand, firms can use scarce absorptive capacities for identifying, assimilating and exploiting external knowledge more efficiently through a combination of relational and transactional search. We demonstrate the usefulness of this theoretical reasoning by identifying contingencies under which the theoretical mechanisms underlying positive complementarity effects are particularly strong. We predict the latter for firms which are technologically lagging (relative to the average firm) and operating in industries with shallow markets for technologies.

We apply a multi-faceted, multi-stage empirical strategy for identifying complementarity effects following latest strategy research (Cassiman and Veugelers, 2006; Golovko and Valentini, 2011; Cassiman and Valentini, 2016). The empirical findings support the general presence of positive complementarity effects between relational and transactional knowledge search. Further, we find that the complementarity effect is particularly strong given shallow markets for technology in a firm's industry. The predicted contingency effect originating from technologically lagging firms is not consistently supported by all empirical tests.

These findings have important implications for academic research and management practice. First, we integrate two research streams in strategy—one focused on a firm's search for knowledge largely assuming relational exchanges (Laursen and Salter, 2006; Leiponen and Helfat, 2010) and one that 
neglects relations in the firm's knowledge search when markets enable transactions (Gans et al., 2008; Arora and Gambardella, 2010). We highlight new opportunities in both research streams by showing that relational and transactional search are neither interchangeable nor isolated from one another. Rather, they are complementary in nature. On the one hand, studies excluding relational or transactional search, respectively, are likely to suffer from biased results. Our findings on complementarity effects indicate that the marginal performance of one is affected by the other. Hence, if both types of search are not modelled simultaneously the direction of the bias is unclear. On the other hand, we show that the complementarity effect is sensitive to market-level effects, i.e. the thickness of the market for technology. This opens a new route for studies on markets for technology focused on how firms can adjust firm-level strategies to balance the weaknesses of market institutions in relation to their knowledge search. More generally, we show that the interaction between relational and transactional search is more complex in terms of how thick the factor markets are.

Second, resource-based theories of strategic management often emphasize the absence of factor markets as an important determinant of whether a resource can constitute a competitive advantage (Barney, 1986; Amit and Schoemaker, 1993). Within these theories, firm knowledge is often described as one such strategic resource (Spender and Grant, 1996). In the absence of factor markets for knowledge, the availability of preferential access through relational search is crucial for maintaining firm-specific knowledge and its competitive potential (Dyer and Hatch, 2006). Our findings extend strategy theory because they contextualize the performance effects of the specificity of a firm's knowledge in environments in which knowledge is available, at least to some degree, on markets for technology. We show that transactional search for knowledge does not necessarily erode competitive advantages from relation-specificity. Instead, a combination of relation-specificity and transactions on markets for technology leads to superior performance effects.

Third, research on markets for technology has struggled to empirically measure the dimensions of such markets across industries and time. Our research suggests a novel measure. Based on a representative 
survey of the innovation activities of German firms, we are able to provide an approximation of the actual amount spent in markets for technology. In that sense, our research extends existing measures, such as the supply of university patents in a particular technological field (Arora and Nandkumar, 2012), which may only cover a certain fraction of the actual market and, therefore, may confound other industry effects. Our research is not limited to a particular industry but maps markets for technology in 20 different industries. In this regard, we are able to distinguish between general industry effects, such as those related to technological opportunities or IPR regimes, and the specific influence of the market for technology. Finally, we can separate the market level (i.e. the thickness of the market for technology) from the actual firm decision within this market, i.e. its transactional search.

These academic implications translate into several implications for management practice and policy making. First, our research helps decision makers responsible for R\&D investments to understand how they can best benefit from an open-innovation strategy (Huston and Sakkab, 2006). Very little guidance exists on how managers should organize their search for external knowledge. Our findings provide evidence that firms forgo performance potentials when they do not combine relational and transactional search. Particularly firms operating in industries with shallow markets for technology can benefit significantly from combining relational and transactional search.

Our results also have implications for policy making as markets for technology are subject to rules and regulations set by governments, such as IPR regulations. Most existing research studies the direct effect of regulatory institutions on transactional search, e.g. in-licensing behavior (Leone and Reichstein, 2012). Our approach is more comprehensive to the degree that it considers a firm's engagment in transactional and relational search simultaneously. We show that differences at the level of the market for technology (i.e. thickness) influence the combined effects of firms' relational and transactional search on innovation performance. Thicker markets for technology increase the choices that firms have in their search for external knowledge. Such markets provide firms with the opportunity to complement costly relational search with transactional search for increased innovation performance. 


\section{CONCLUDING REMARKS}

While our research makes several contributions to two important streams of literature, we acknowledge two limitations that translate into opportunities for future research. First, the structure of our data does not allow us to follow firms' investments in search and in markets for technology over time. Although we are able to measure inputs and outputs of the firm's knowledge production at different points in time, the number of firms that we are able to observe over time is low. This limitation of the data has precluded our ability to estimate a fixed-effects model which would generally be desirable to address endogeneity concerns in a more complete way than what we could do by instrumenting the search strategies.

Therefore, generating more longitudinal datasets that could provide insight into the firm's decisions regarding knowledge search over time-and the corresponding implications for innovation performance—would be desirable.

Second, our study emphasizes the interrelationships between relational and transactional search. Our interviews with R\&D managers support the theoretical reasoning for complementarity effects. However, we have also learned that firms are heterogeneous in the procedures, criteria, decision making and timing processes for comparing relational and transactional search activities. We encourage dedicated studies which explore these heterogeneities in the management of combined relational and transactional knowledge search as well as the performance effects in a systematic way.

\section{REFERENCES}

Agrawal A. 2006. Engaging the Inventor: Exploring Licensing Strategies for University Inventions and the Role of Latent Knowledge. Strategic Management Journal 27(1): 63-79.

Agrawal A, Cockburn I, Zhang L. 2015. Deals Not Done: Sources of Failure in the Market for Ideas. Strategic Management Journal 36(7): 976-986.

Ahuja G, Lampert CM, Tandon V. 2008. Moving Beyond Schumpeter: Management Research on the Determinants of Technological Innovation. Academy of Management Annals 2: 1 - 98.

Amit R, Schoemaker PJH. 1993. Strategic Assets and Organizational Rent. Strategic Management Journal 14(1): 33-46.

Arora A, Fosfuri A, Gambardella A. 2001. Markets for Technology: The Economics of Innovation and Corporate Strategy. MIT Press: Cambridge, MA.

Arora A, Gambardella A. 2010. Ideas for Rent: An Overview of Markets for Technology. Industrial and Corporate Change 19(3): 775-803. 
Arora A, Nandkumar A. 2012. Insecure Advantage? Markets for Technology and the Value of Resources for Entrepreneurial Ventures. Strategic Management Journal 33(3): 231-251.

Arundel A, Kabla I. 1998. What Percentage of Innovations Are Patented? Empirical Estimates for European Firms. Research Policy 27: 127-141.

Arvanitis S, Lokshin B, Mohnen P, Woerter M. 2015. Impact of External Knowledge Acquisition Strategies on Innovation: A Comparative Study Based on Dutch and Swiss Panel Data. Review of Industrial Organization 46(4): 359-382.

Athey S, Stern S. 1998. An Empirical Framework for Testing Theories About Complementarity in Organizational Design, NBER Working Paper: Boston.

Bäck I, Kohtamäki M. 2016. Joint Learning in Innovative R\&D Collaboration. Industry and innovation 23(1): 62-86.

Baker G, Gibbons R, Murphy KJ. 2002. Relational Contracts and the Theory of the Firm. The Quarterly Journal of Economics 117(1): 39-84.

Barney JB. 1986. Strategic Factor Markets. Expectations, Luck, and Business Strategy. Management Science 32(10): 1231-1241.

Belsley DA, Kuh E, Welsh RE. 1980. Regression Diagnostics: Identifying Influential Data and Sources of Collinearity: New York.

Cassiman B, Golovko E. 2011. Innovation and Internationalization through Exports. Journal of International Business Studies 42(1): 56-75.

Cassiman B, Valentini G. 2016. Open Innovation: Are Inbound and Outbound Knowledge Flows Really Complementary? Strategic Management Journal 37(6): 1034-1046.

Cassiman B, Veugelers R. 2006. In Search of Complementarity in Innovation Strategy: Internal R\&D and External Knowledge Acquisition. Management Science 52(1): 68-82.

Chesbrough HW. 2003. Open Innovation: The New Imperative for Creating and Profiting from Technology. Harvard Business School Publishing: Cambridge, MA.

Cohen WM, Levinthal DA. 1989. Innovation and Learning: The Two Faces of R\&D. The Economic Journal 99: 569-596.

Conti R, Gambardella A, Novelli E. 2013. Research on Markets for Inventions and Implications for R\&D Allocation Strategies. Academy of Management Annals 7(1): 715-772.

Dushnitsky G, Klueter T. 2011. Is There an Ebay for Ideas? Insights from Online Knowledge Marketplaces. European Management Review 8(1): 17-32.

Dyer JH, Hatch NW. 2006. Relation-Specific Capabilities and Barriers to Knowledge Transfers: Creating Advantage through Network Relationships. Strategic Management Journal 27(8): 701-719.

Dyer JH, Singh H. 1998. The Relational View: Cooperative Strategy and Sources of Interorganizational Competitive Advantage. Academy of Management Review 23: 660-679.

Edler J, Polt W. 2008. International Industrial R\&D - Policy Challenges: Introduction to the Special Issue. Journal of Technology Transfer 33: 331-336.

Encaoua D, Guellec D, Martinez C. 2006. Patent Systems for Encouraging Innovation: Lessons from Economic Analysis. Research Policy 35(9): 1423-1440.

Eurostat. 2009. Fifth Community Innovation Survey: Synthesis of Quality Reports. Office for Official Publications of the European Communities: Luxembourg.

Felin T, Zenger TR. 2014. Closed or Open Innovation? Problem Solving and the Governance Choice. Research Policy 43(5): 914-925.

Fleming L, Sorenson O. 2004. Science as a Map in Technology Search. Strategic Management Journal 25(8-9): 909-928.

Gambardella A, Giuri P, Luzzi A. 2007. The Market for Patents in Europe. Research Policy 36(8): 11631183.

Gans JS, Hsu DH, Stern S. 2008. The Impact of Uncertain Intellectual Property Rights on the Market for Ideas: Evidence from Patent Grant Delays. Management Science 54(5): 982-997.

Gans JS, Stern S. 2003. The Product Market and the Market for "Ideas": Commercialization Strategies for Technology Entrepreneurs. Research Policy 32(2): 333-350. 
Gans JS, Stern S. 2010. Is There a Market for Ideas? Industrial and Corporate Change 19(3): 805-837.

Golovko E, Valentini G. 2011. Exploring the Complementarity between Innovation and Export for Smes' Growth. Journal of International Business Studies 42: 362-380.

Grant RM. 1996. Toward a Knowledge-Based Theory of the Firm. Strategic Management Journal 17: 109-122.

Greif A. 1989. Reputation and Coalitions in Medieval Trade: Evidence on the Maghribi Traders. Journal of Economic History 49(4): 857-882.

Greif A. 1993. Contract Enforceability and Economic Institutions in Early Trade: The Maghribi Traders' Coalition. American Economic Review 83(3): 525-548.

Griliches Z. 1979. Issues in Assessing the Contribution of Research and Development to Productivity Growth. Bell Journal of Economics 10(1): 92-116.

Grimpe C, Kaiser U. 2010. Balancing Internal and External Knowledge Acquisition: The Gains and Pains from R\&D Outsourcing. Journal of Management Studies 47(8): 1483-1509.

Grimpe C, Sofka W. 2009. Search Patterns and Absorptive Capacity: Low- and High-Technology Sectors in European Countries. Research Policy 38: 495-506.

Hall BH, Helmers C, Rogers M, Sena V. 2014. The Choice between Formal and Informal Intellectual Property: A Review. Journal of Economic Literature 52(2): 1-50.

Hall BH, Jaffe AB, Trajtenberg M. 2005. Market Value and Patent Citations. RAND Journal of Economics(Spring): 16-38.

Helfat CE. 1994. Firm-Specificity in Corporate Applied R\&D. Organization Science 5(2): 173-184.

Henderson R, Cockburn I. 1996. Scale, Scope, and Spillovers: Determinants of Research Productivity in the Pharmaceutical Industry. RAND Journal of Economics 27(1): 32-59.

Holloway SS, Parmigiani A. 2016. Friends and Profits Don't Mix: The Performance Implications of Repeated Partnerships. Academy of Management Journal 59(2): 460-478.

Huston L, Sakkab N. 2006. Connect and Develop. Harvard Business Review 84(3): 58-66.

Katila R, Ahuja G. 2002. Something Old, Something New: A Longitudinal Study of Search Behavior and New Product Introduction. Academy of Management Journal 45(6): 1183-1194.

Klingebiel R, Adner R. 2015. Real Options Logic Revisited: The Performance Effects of Alternative Resource Allocation Regimes. Academy of Management Journal 58(1): 221-241.

Kogut R, Zander U. 1992. Knowledge of the Firm, Combinative Capabilities and the Replication of Technology. Organization Science 33(3): 383-397.

Koput KW. 1997. A Chaotic Model of Innovative Search: Some Answers, Many Questions. Organization Science 8(5): 528-542.

Kumar S, Russell RR. 2002. Technological Change, Technological Catch-up, and Capital Deepening: Relative Contributions to Growth and Convergence. American Economic Review 92(3): 527-548.

Lamoreaux NR, Sokoloff KL. 2001. Market Trade in Patents and the Rise of a Class of Specialized Inventors in the 19th-Century United States. American Economic Review 91(2): 39-44.

Laursen K. 2012. Keep Searching and You'll Find: What Do We Know About Variety Creation through Firms’ Search Activities for Innovation? Industrial \& Corporate Change 21(5): 1175-1180.

Laursen K, Salter A. 2006. Open for Innovation: The Role of Openness in Explaining Innovation Performance among U.K. Manufacturing Firms. Strategic Management Journal 27: 131-150.

Leiponen A, Helfat CE. 2010. Innovation Objectives, Knowledge Sources, and the Benefits of Breadth. Strategic Management Journal 31(2): 224-236.

Leiponen A, Helfat CE. 2011. Location, Decentralization, and Knowledge Sources for Innovation. Organization Science 22: 641-658.

Leone MI, Reichstein T. 2012. Licensing-in Fosters Rapid Invention! The Effect of the Grant-Back Clause and Technological Unfamiliarity. Strategic Management Journal 33(8): 965-985.

Maddala GS. 1983. Limited-Dependent and Qualitative Variables in Economics. Cambridge University Press: New York.

Mahmood IP, Rufin C. 2005. Government's Dilemma: The Role of Government in Imitation and Innovation. Academy of Management Review 30(2): 338-360. 
McCain RA. 1977. The Characteristics of Optimum Inventions: An Isotech Approach. American Economic Review 67(1): 365-369.

Milgrom P, Roberts J. 1990. The Economics of Modern Manufacturing: Technology, Strategy, and Organization. American Economic Review 80(3): 511-528.

Nerkar A, Shane S. 2007. Determinants of Invention Commercialization: An Empirical Examination of Academically Sourced Inventions. Strategic Management Journal 28(11): 1155-1166.

OECD. 2005. Oslo Manual: Guidelines for Collecting and Interpreting Innovation Data (3rd ed.). Organisation for Economic Co-operation and Development: Paris.

OECD. 2009. Science, Technology and Industry Scoreboard: Paris.

Peters B, Rammer C. 2013. Innovation Panel Surveys in Germany. In F Gault (Ed.), Handbook of Innovation Indicators and Measurement. Edward Elgar: Cheltenham and Northampton: 135-177.

Poppo L, Zenger T. 2002. Do Formal Contracts and Relational Governance Function as Substitutes or Complements? Strategic Management Journal 23(8): 707-725.

Rammer C, Peters B, Schmidt T, Aschhoff B, Doherr T, Niggemann H. 2005. Innovationen in Deutschland. Ergebnisse Der Innovationserhebung 2003 in Der Deutschen Wirtschaft. Nomos: Baden-Baden.

Robbins C. 2006. Measuring Payments for the Supply and Use of Intellectual Property. Bureau of Economic Analysis, U.S. Department of Commerce: Washington, D.C.

Rosenkopf L, Nerkar A. 2001. Beyond Local Search: Boundary-Spanning, Exploration, and Impact in the Optical Disc Industry. Strategic Management Journal 22(4): 287-306.

Roth A. 2007. The Art of Designing Markets. Harvard Business Review October: 1-9.

Salomon R, Jin B. 2010. Do Leading or Lagging Firms Learn More from Exporting? Strategic Management Journal 31(10): 1088-1113.

Sinclair G, Klepper S, Cohen W. 2000. What's Experience Got to Do with It? Sources of Cost Reduction in a Large Specialty Chemicals Producer. Management Science 46(1): 28-45.

Spender J-C, Grant RM. 1996. Knowledge and the Firm: An Overview. Strategic Management Journal 17(Winter Special Issue): 5-9.

Teece DJ. 1986. Profiting from Technological Innovation. Implications for Integration, Collaboration, Licensing and Public Policy. Research Policy 15(6): 285-305.

Todorova G, Durisin B. 2007. Absorptive Capacity: Valuing a Reconceptualization. Academy of Management Review 32(3): 774-786.

Wang HC, He J, Mahoney JT. 2009. Firm-Specific Knowledge Resources and Competitive Advantage: The Roles of Economic- and Relationship-Based Employee Governance Mechanisms. Strategic Management Journal 30(12): 1265-1285.

Wooldridge JM. 2007. Econometric Analysis of Cross Section and Panel Data (2. ed.): Cambridge, MA. Yanagisawa T, Guellec D. 2009. The Emerging Patent Marketplace. OECD STI Working Paper(2009/9): $1-52$. 


\section{TABLES}

Table 1: Comparison of relational and transactional knowledge search

\begin{tabular}{|c|c|c|}
\hline Search process & Relational & Transactional \\
\hline $\begin{array}{l}\text { Type of knowledge that can be } \\
\text { acquired }\end{array}$ & $\begin{array}{l}\text { All technology development stages; } \\
\text { codified or tacit }\end{array}$ & $\begin{array}{l}\text { Only codifiable knowledge (in a } \\
\text { patent or technical documentation) } \\
\text { which is ready to use }\end{array}$ \\
\hline $\begin{array}{l}\text { Scope of available external } \\
\text { knowledge }\end{array}$ & Limited by firm’s search capacity & Limited by supply of technology \\
\hline $\begin{array}{l}\text { Uniqueness of acquired } \\
\text { knowledge }\end{array}$ & Potentially high & $\begin{array}{l}\text { Low; knowledge is in principle also } \\
\text { available to competitors }\end{array}$ \\
\hline Transfer of knowledge & $\begin{array}{l}\text { Typically requires relation-specific } \\
\text { investment with knowledge source }\end{array}$ & Transaction \\
\hline $\begin{array}{l}\text { Costs for identification of } \\
\text { knowledge sources }\end{array}$ & High and firm-specific & $\begin{array}{l}\text { Low and at least partially born by } \\
\text { knowledge suppliers }\end{array}$ \\
\hline $\begin{array}{l}\text { Flexibility for entering new } \\
\text { search directions }\end{array}$ & $\begin{array}{l}\text { Low; limited by relation-specific } \\
\text { investments with existing knowledge } \\
\text { sources }\end{array}$ & High \\
\hline $\begin{array}{l}\text { Opportunity for comparing } \\
\text { alternative technological solutions }\end{array}$ & $\begin{array}{l}\text { Low; limited by relation-specific } \\
\text { investments with existing knowledge } \\
\text { sources }\end{array}$ & $\begin{array}{l}\text { High; limited by supply side of } \\
\text { market }\end{array}$ \\
\hline
\end{tabular}

Table 2: Average innovation performance for each search strategy

\begin{tabular}{l|c|c|c}
\hline & $\begin{array}{c}\text { Frequency of search } \\
\text { strategy }\end{array}$ & $\begin{array}{c}\text { Innovation sales } \\
\text { (mn EUR) }\end{array}$ & $\begin{array}{c}\text { Share of innovation } \\
\text { sales }\end{array}$ \\
\hline No COLLABORATE no BUY & $1640(41.8 \%)$ & 11.50 & 0.27 \\
Only COLLABORATE & $477(12.2 \%)$ & 16.11 & 0.30 \\
Only BUY & $860(21.9 \%)$ & 17.22 & 0.28 \\
COLLABORATE and BUY & $944(24.1 \%)$ & 85.40 & 0.34 \\
Total & $3921(100.0 \%)$ & 31.10 & 0.29 \\
\hline
\end{tabular}

A t-test shows that the difference between the COLLABORATE and BUY strategy and the other strategies for both innovation performance measures is statistically significant at the $1 \%$ level. 
Table 3: Summary statistics

\begin{tabular}{|c|c|c|c|c|c|c|}
\hline \multirow[b]{2}{*}{ Variable } & \multicolumn{2}{|c|}{$\begin{array}{l}\text { All firms } \\
\text { (3921) }\end{array}$} & \multicolumn{2}{|c|}{$\begin{array}{c}\text { COLLABORATE }=1 \\
(1421)\end{array}$} & \multicolumn{2}{|c|}{$\begin{array}{c}\text { BUY = } 1 \\
(1804)\end{array}$} \\
\hline & Mean & Std. dev. & Mean & Std. dev. & Mean & Std. dev. \\
\hline Innovation sales (mn EUR) & 31.10 & 290.90 & 62.14 & 471.34 & 52.89 & 419.76 \\
\hline Past performance & 0.35 & 0.61 & 0.34 & 0.58 & 0.35 & 0.49 \\
\hline R\&D intensity & 0.04 & 0.10 & 0.08 & 0.14 & 0.06 & 0.12 \\
\hline Patent stock per employee & 0.01 & 0.04 & 0.02 & 0.05 & 0.01 & 0.04 \\
\hline Export intensity & 0.23 & 0.27 & 0.30 & 0.28 & 0.27 & 0.28 \\
\hline Process innovator (d) & 0.57 & 0.49 & 0.64 & 0.48 & 0.64 & 0.48 \\
\hline No of employees & 593.92 & 6585.22 & 1165.12 & 10811.39 & 839.70 & 7878.48 \\
\hline Part of group (d) & 0.42 & 0.49 & 0.46 & 0.50 & 0.48 & 0.50 \\
\hline Mining (d) & 0.01 & 0.08 & 0.01 & 0.09 & 0.01 & 0.08 \\
\hline Food/tobacco (d) & 0.04 & 0.18 & 0.02 & 0.14 & 0.02 & 0.15 \\
\hline Textiles (d) & 0.02 & 0.16 & 0.02 & 0.14 & 0.02 & 0.14 \\
\hline Wood/paper (d) & 0.05 & 0.21 & 0.02 & 0.15 & 0.04 & 0.20 \\
\hline Chemicals (d) & 0.06 & 0.24 & 0.09 & 0.28 & 0.07 & 0.25 \\
\hline Plastics (d) & 0.05 & 0.21 & 0.04 & 0.19 & 0.03 & 0.18 \\
\hline Glass/ceramics (d) & 0.03 & 0.17 & 0.03 & 0.16 & 0.03 & 0.16 \\
\hline Metals (d) & 0.07 & 0.26 & 0.06 & 0.24 & 0.07 & 0.25 \\
\hline Machinery/equipment (d) & 0.11 & 0.32 & 0.15 & 0.36 & 0.13 & 0.34 \\
\hline Electronics (d) & 0.09 & 0.28 & 0.10 & 0.30 & 0.09 & 0.29 \\
\hline Instruments/optics (d) & 0.08 & 0.27 & 0.12 & 0.32 & 0.10 & 0.30 \\
\hline Vehicles (d) & 0.03 & 0.18 & 0.04 & 0.19 & 0.04 & 0.21 \\
\hline Furniture/nec. (d) & 0.03 & 0.16 & 0.02 & 0.13 & 0.02 & 0.15 \\
\hline Wholesale trade (d) & 0.03 & 0.17 & 0.02 & 0.14 & 0.02 & 0.16 \\
\hline Transportation (d) & 0.04 & 0.18 & 0.01 & 0.10 & 0.03 & 0.17 \\
\hline Financial (d) & 0.04 & 0.19 & 0.02 & 0.13 & 0.03 & 0.17 \\
\hline IT/telecommunication (d) & 0.07 & 0.26 & 0.07 & 0.26 & 0.08 & 0.27 \\
\hline Technology-oriented services (d) & 0.09 & 0.29 & 0.14 & 0.35 & 0.10 & 0.30 \\
\hline Knowledge-intensive services (d) & 0.03 & 0.18 & 0.02 & 0.14 & 0.03 & 0.16 \\
\hline Other services (d) & 0.04 & 0.19 & 0.02 & 0.12 & 0.03 & 0.16 \\
\hline Survey year 2001 (d) & 0.28 & 0.45 & 0.28 & 0.45 & 0.29 & 0.45 \\
\hline Survey year 2005 (d) & 0.32 & 0.47 & 0.30 & 0.46 & 0.32 & 0.47 \\
\hline Survey year 2009 (d) & 0.39 & 0.49 & 0.42 & 0.49 & 0.39 & 0.49 \\
\hline
\end{tabular}

(d) dummy variable

Table 4: Correlation coefficients

\begin{tabular}{llrrrrrrrrrr}
\hline & Variable & 1 & 2 & 3 & 4 & 5 & 6 & 7 & 8 & 9 & 10 \\
\hline 1 & Only COLLABORATE (d) & 1.00 & & & & & & & & & \\
2 & Only BUY (d) & -0.20 & 1.00 & & & & & & & \\
3 & COLLABORATE and BUY (d) & -0.21 & -0.30 & 1.00 & & & & & & \\
4 & Past performance & -0.01 & 0.02 & -0.01 & 1.00 & & & & & \\
5 & 0.12 & -0.10 & 0.23 & -0.10 & 1.00 & & & & \\
6 & Patent stock per employee & 0.07 & -0.03 & 0.12 & 0.00 & 0.20 & 1.00 & & & \\
7 & Export intensity & 0.03 & -0.03 & 0.19 & 0.06 & 0.04 & 0.21 & 1.00 & & & \\
8 & Process innovator (d) & -0.01 & 0.03 & 0.12 & 0.02 & -0.01 & 0.00 & 0.04 & 1.00 & & \\
9 & No of employees (log) & -0.05 & 0.06 & 0.17 & 0.13 & -0.19 & 0.00 & 0.30 & 0.21 & 1.00 & \\
10 & Part of group (d) & -0.03 & 0.04 & 0.10 & 0.16 & -0.10 & 0.05 & 0.22 & 0.12 & 0.50 & 1.00 \\
\hline
\end{tabular}


Table 5: Random-effects Tobit regression results for innovation performance

\begin{tabular}{|c|c|c|c|c|c|c|}
\hline & $\begin{array}{c}(1) \\
\text { Full sample }\end{array}$ & $\begin{array}{c}\text { (2) } \\
\text { Full sample }\end{array}$ & $\begin{array}{c}(3) \\
\text { Leaders }\end{array}$ & $\begin{array}{c}(4) \\
\text { Laggards }\end{array}$ & $\begin{array}{c}\text { (5) } \\
\text { Thick markets }\end{array}$ & $\begin{array}{c}(6) \\
\text { Shallow markets }\end{array}$ \\
\hline Collaborate only (d) & & $\begin{array}{c}0.01 \\
(0.04)\end{array}$ & $\begin{array}{c}0.05 \\
(0.05)\end{array}$ & $\begin{array}{l}-0.10^{*} \\
(0.06)\end{array}$ & $\begin{array}{c}0.02 \\
(0.05)\end{array}$ & $\begin{array}{l}-0.01 \\
(0.06)\end{array}$ \\
\hline Buy only (d) & & $\begin{array}{c}0.03 \\
(0.03)\end{array}$ & $\begin{array}{c}0.08 \\
(0.05)\end{array}$ & $\begin{array}{l}-0.01 \\
(0.04)\end{array}$ & $\begin{array}{c}0.03 \\
(0.05)\end{array}$ & $\begin{array}{c}0.04 \\
(0.04)\end{array}$ \\
\hline Collaborate and Buy (d) & & $\begin{array}{l}0.14 * * * \\
(0.03)\end{array}$ & $\begin{array}{c}0.06 \\
(0.05)\end{array}$ & $\begin{array}{l}0.18 * * * \\
(0.05)\end{array}$ & $\begin{array}{c}0.08 \\
(0.05)\end{array}$ & $\begin{array}{l}0.20 * * * \\
(0.05)\end{array}$ \\
\hline Past performance & $\begin{array}{l}0.40 * * * \\
(0.02)\end{array}$ & $\begin{array}{l}0.40 * * * \\
(0.02)\end{array}$ & $\begin{array}{l}0.51 * * * \\
(0.04)\end{array}$ & $\begin{array}{l}0.39 * * * \\
(0.02)\end{array}$ & $\begin{array}{l}0.35 * * * \\
(0.02)\end{array}$ & $\begin{array}{l}0.52 * * * \\
(0.03)\end{array}$ \\
\hline R\&D intensity & $\begin{array}{l}0.38^{* * *} \\
(0.14)\end{array}$ & $\begin{array}{l}0.28^{* *} \\
(0.14)\end{array}$ & $\begin{array}{c}2.31 \\
(2.59)\end{array}$ & $\begin{array}{c}6.42 \\
(4.07)\end{array}$ & $\begin{array}{c}0.24 \\
(0.15)\end{array}$ & $\begin{array}{l}0.70^{* *} \\
(0.32)\end{array}$ \\
\hline Patent stock per employee & $\begin{array}{l}1.00 * * * \\
(0.35)\end{array}$ & $\begin{array}{l}0.95^{* * *} \\
(0.35)\end{array}$ & $\begin{array}{l}0.84 * * * \\
(0.32)\end{array}$ & $\begin{array}{c}1.32 \\
(0.98)\end{array}$ & $\begin{array}{c}0.68^{*} \\
(0.37)\end{array}$ & $\begin{array}{l}2.44^{* * * *} \\
(0.85)\end{array}$ \\
\hline Export intensity & $\begin{array}{l}0.37 * * * \\
(0.06)\end{array}$ & $\begin{array}{l}0.35 * * * \\
(0.06)\end{array}$ & $\begin{array}{l}0.27 * * * \\
(0.08)\end{array}$ & $\begin{array}{l}0.34 * * * \\
(0.08)\end{array}$ & $\begin{array}{l}0.34 * * * \\
(0.07)\end{array}$ & $\begin{array}{l}0.33^{* * * *} \\
(0.08)\end{array}$ \\
\hline Process innovator (d) & $\begin{array}{l}0.15^{* * *} \\
(0.03)\end{array}$ & $\begin{array}{l}0.14 * * * \\
(0.03)\end{array}$ & $\begin{array}{l}0.12 * * * \\
(0.04)\end{array}$ & $\begin{array}{l}0.14^{* * *} \\
(0.04)\end{array}$ & $\begin{array}{l}0.10^{* * *} \\
(0.04)\end{array}$ & $\begin{array}{l}0.18^{* * * *} \\
(0.04)\end{array}$ \\
\hline No of employees (log) & $\begin{array}{l}0.63 * * * \\
(0.01)\end{array}$ & $\begin{array}{l}0.62 * * * \\
(0.01)\end{array}$ & $\begin{array}{l}0.66 * * * \\
(0.01)\end{array}$ & $\begin{array}{l}0.60 * * * \\
(0.01)\end{array}$ & $\begin{array}{l}0.66 * * * \\
(0.01)\end{array}$ & $\begin{array}{l}0.58^{* * * *} \\
(0.01)\end{array}$ \\
\hline Part of group (d) & $\begin{array}{l}0.09 * * * \\
(0.03)\end{array}$ & $\begin{array}{l}0.09 * * * \\
(0.03)\end{array}$ & $\begin{array}{l}0.10^{* *} \\
(0.04)\end{array}$ & $\begin{array}{l}0.08^{* *} \\
(0.04)\end{array}$ & $\begin{array}{c}0.04 \\
(0.04)\end{array}$ & $\begin{array}{l}0.15^{* * *} \\
(0.04)\end{array}$ \\
\hline Firm R\&D - industry R\&D & & & $\begin{array}{l}-2.18 \\
(2.59)\end{array}$ & $\begin{array}{l}-3.10 \\
(3.88)\end{array}$ & & \\
\hline Market thickness & & & & & $\begin{array}{l}2.32 * * \\
(1.11)\end{array}$ & $\begin{array}{l}-1.24 \\
(1.74)\end{array}$ \\
\hline Industry dummies & included & included & included & included & included & included \\
\hline Survey year dummies & included & included & included & included & included & included \\
\hline Constant & $\begin{array}{l}-1.70^{* * *} \\
(0.06)\end{array}$ & $\begin{array}{l}-1.71 * * * \\
(0.06)\end{array}$ & $\begin{array}{l}-1.78^{* * *} \\
(0.12)\end{array}$ & $\begin{array}{l}-1.80^{* * *} \\
(0.15)\end{array}$ & $\begin{array}{l}-2.07 * * * \\
(0.15)\end{array}$ & $\begin{array}{l}-2.01 * * * \\
(0.13)\end{array}$ \\
\hline Complementarity test & & $\begin{array}{c}\text { Chi2(1)= } \\
\text { 3.15* }\end{array}$ & $\begin{array}{c}\text { Chi2(1)= } \\
0.88\end{array}$ & $\begin{array}{l}\text { Chi2(1)= } \\
13.85^{* * *}\end{array}$ & $\begin{array}{c}\text { Chi2(1)= } \\
0.23\end{array}$ & $\begin{array}{c}\text { Chi2(1)= } \\
\text { 4.39** }\end{array}$ \\
\hline $\begin{array}{l}\mathrm{N} \\
\text { F-statistic / Wald Chi2 }\end{array}$ & $\begin{array}{c}3921 \\
9104.49 * * *\end{array}$ & $\begin{array}{c}3921 \\
8769.14^{* * *}\end{array}$ & $\begin{array}{c}1593 \\
5357.95^{* * * *}\end{array}$ & $\begin{array}{c}2328 \\
4752.80^{* * *}\end{array}$ & $\begin{array}{c}2021 \\
5358.31^{* * *}\end{array}$ & $\begin{array}{c}1900 \\
4319.05^{* * *}\end{array}$ \\
\hline
\end{tabular}

Coefficients are shown; standard errors in parentheses; (d) dummy variable; ${ }^{*} \mathrm{p}<0.10,{ }^{* *} \mathrm{p}<0.05,{ }^{* * *} \mathrm{p}<0.01$

Industry dummies are jointly significant in each model; survey year dummies are not significant. 
APPENDIX

\section{(1) Tests of complementarity using pooled Tobit and OLS regression models}

We estimate our main models using pooled (with Huber-White standard errors clustered by firm) Tobit and OLS regression models to check whether our results are sensitive to a different type of model. Table 6 (Table 7) shows the results of the Tobit models (OLS models) which are consistent with the randomeffects models. 
Table 6: Pooled Tobit regression results for innovation performance

\begin{tabular}{|c|c|c|c|c|c|c|}
\hline & $\begin{array}{c}\text { (7) } \\
\text { Full sample }\end{array}$ & $\begin{array}{c}\text { (8) } \\
\text { Full sample }\end{array}$ & $\begin{array}{c}(9) \\
\text { Leaders }\end{array}$ & $\begin{array}{c}(10) \\
\text { Laggards }\end{array}$ & $\begin{array}{c}\text { (11) } \\
\text { Thick markets }\end{array}$ & $\begin{array}{c}(12) \\
\text { Shallow markets }\end{array}$ \\
\hline Collaborate only (d) & & $\begin{array}{l}-0.01 \\
(0.04)\end{array}$ & $\begin{array}{c}0.06 \\
(0.05)\end{array}$ & $\begin{array}{l}-0.12^{*} \\
(0.06)\end{array}$ & $\begin{array}{c}0.00 \\
(0.05)\end{array}$ & $\begin{array}{l}-0.03 \\
(0.06)\end{array}$ \\
\hline Buy only (d) & & $\begin{array}{c}0.05 \\
(0.03)\end{array}$ & $\begin{array}{l}0.10^{* *} \\
(0.05)\end{array}$ & $\begin{array}{l}-0.01 \\
(0.04)\end{array}$ & $\begin{array}{c}0.04 \\
(0.05)\end{array}$ & $\begin{array}{c}0.05 \\
(0.05)\end{array}$ \\
\hline Collaborate and Buy (d) & & $\begin{array}{l}0.15 * * * \\
(0.04)\end{array}$ & $\begin{array}{c}0.07 \\
(0.05)\end{array}$ & $\begin{array}{l}0.19 * * * \\
(0.06)\end{array}$ & $\begin{array}{c}0.08^{*} \\
(0.05)\end{array}$ & $\begin{array}{l}0.21^{* * *} \\
(0.05)\end{array}$ \\
\hline Past performance & $\begin{array}{l}0.43^{* * *} \\
(0.07)\end{array}$ & $\begin{array}{l}0.43^{* * * *} \\
(0.07)\end{array}$ & $\begin{array}{l}0.54 * * * \\
(0.17)\end{array}$ & $\begin{array}{l}0.41^{* * *} \\
(0.08)\end{array}$ & $\begin{array}{l}0.38 * * * \\
(0.09)\end{array}$ & $\begin{array}{l}0.53^{* * *} \\
(0.09)\end{array}$ \\
\hline R\&D intensity & $\begin{array}{l}0.42^{* * *} \\
(0.10)\end{array}$ & $\begin{array}{l}0.30 * * * \\
(0.11)\end{array}$ & $\begin{array}{c}1.61 \\
(2.35)\end{array}$ & $\begin{array}{c}6.12 \\
(3.78)\end{array}$ & $\begin{array}{l}0.28^{* *} \\
(0.12)\end{array}$ & $\begin{array}{l}0.69 * * * \\
(0.25)\end{array}$ \\
\hline Patent stock per employee & $\begin{array}{l}1.07 * * * \\
(0.40)\end{array}$ & $\begin{array}{l}1.01^{* * *} \\
(0.38)\end{array}$ & $\begin{array}{l}0.78^{* *} \\
(0.31)\end{array}$ & $\begin{array}{c}2.25^{*} \\
(1.24)\end{array}$ & $\begin{array}{l}0.79 * * \\
(0.38)\end{array}$ & $\begin{array}{l}2.27 * * * \\
(0.86)\end{array}$ \\
\hline Export intensity & $\begin{array}{l}0.38 * * * \\
(0.06)\end{array}$ & $\begin{array}{l}0.36 * * * \\
(0.06)\end{array}$ & $\begin{array}{l}0.29 * * * \\
(0.07)\end{array}$ & $\begin{array}{l}0.32 * * * \\
(0.09)\end{array}$ & $\begin{array}{l}0.35^{* * * *} \\
(0.08)\end{array}$ & $\begin{array}{l}0.34^{* * * *} \\
(0.08)\end{array}$ \\
\hline Process innovator (d) & $\begin{array}{l}0.15^{* * *} \\
(0.02)\end{array}$ & $\begin{array}{l}0.14 * * * \\
(0.02)\end{array}$ & $\begin{array}{l}0.12 * * * \\
(0.04)\end{array}$ & $\begin{array}{l}0.14^{* * *} \\
(0.03)\end{array}$ & $\begin{array}{l}0.09 * * * \\
(0.03)\end{array}$ & $\begin{array}{l}0.19 * * * \\
(0.04)\end{array}$ \\
\hline No of employees (log) & $\begin{array}{l}0.63 * * * \\
(0.01)\end{array}$ & $\begin{array}{l}0.62 * * * \\
(0.01)\end{array}$ & $\begin{array}{l}0.67 * * * \\
(0.02)\end{array}$ & $\begin{array}{l}0.60 * * * \\
(0.02)\end{array}$ & $\begin{array}{l}0.66 * * * \\
(0.02)\end{array}$ & $\begin{array}{l}0.58^{* * *} \\
(0.02)\end{array}$ \\
\hline Part of group (d) & $\begin{array}{l}0.10^{* * *} \\
(0.03)\end{array}$ & $\begin{array}{l}0.09 * * * \\
(0.03)\end{array}$ & $\begin{array}{l}0.09 * \\
(0.05)\end{array}$ & $\begin{array}{l}0.09 * * \\
(0.04)\end{array}$ & $\begin{array}{c}0.03 \\
(0.04)\end{array}$ & $\begin{array}{l}0.15^{* * *} \\
(0.05)\end{array}$ \\
\hline Firm R\&D - industry R\&D & & & $\begin{array}{l}-1.44 \\
(2.36)\end{array}$ & $\begin{array}{l}-2.71 \\
(3.23)\end{array}$ & & \\
\hline Market thickness & & & & & $\begin{array}{c}2.01 \\
(1.33)\end{array}$ & $\begin{array}{l}-1.09 \\
(1.75)\end{array}$ \\
\hline Industry dummies & included & included & included & included & included & included \\
\hline Survey year dummies & included & included & included & included & included & included \\
\hline Constant & $\begin{array}{l}-1.71^{* * *} \\
(0.06)\end{array}$ & $\begin{array}{l}-1.72 * * * \\
(0.06)\end{array}$ & $\begin{array}{l}-1.80 * * * \\
(0.12)\end{array}$ & $\begin{array}{l}-1.78^{* * *} \\
(0.13)\end{array}$ & $\begin{array}{l}-2.04 * * * \\
(0.17)\end{array}$ & $\begin{array}{l}-2.01 * * * \\
(0.14)\end{array}$ \\
\hline Complementarity test & & $\begin{array}{c}\mathrm{F}(1,3890)= \\
4.26^{* *}\end{array}$ & $\begin{array}{c}\mathrm{F}(1,1561)= \\
1.60\end{array}$ & $\begin{array}{c}\mathrm{F}(1,2296)= \\
14.24^{* * *}\end{array}$ & $\begin{array}{c}\mathrm{F}(1,1993)= \\
0.33\end{array}$ & $\begin{array}{c}\mathrm{F}(1,1871)= \\
5.22^{* *}\end{array}$ \\
\hline $\begin{array}{l}\mathrm{N} \\
\text { F-statistic / Wald Chi2 }\end{array}$ & $\begin{array}{c}3921 \\
158.95^{* * *}\end{array}$ & $\begin{array}{c}3921 \\
146.45 * * *\end{array}$ & $\begin{array}{c}1593 \\
81.09 * * *\end{array}$ & $\begin{array}{c}2328 \\
84.10 * * *\end{array}$ & $\begin{array}{c}2021 \\
79.27 * * *\end{array}$ & $\begin{array}{c}1900 \\
113.94 * * *\end{array}$ \\
\hline
\end{tabular}

Coefficients are shown; standard errors in parentheses; (d) dummy variable; ${ }^{*} \mathrm{p}<0.10,{ }^{* *} \mathrm{p}<0.05,{ }^{* * *} \mathrm{p}<0.01$

Industry dummies are jointly significant in each model; survey year dummies are not significant. 
Table 7: OLS regression results for innovation performance

\begin{tabular}{|c|c|c|c|c|c|c|}
\hline & $\begin{array}{c}\text { (13) } \\
\text { Full sample }\end{array}$ & $\begin{array}{c}(14) \\
\text { Full sample }\end{array}$ & $\begin{array}{c}(15) \\
\text { Leaders }\end{array}$ & $\begin{array}{c}(16) \\
\text { Laggards }\end{array}$ & $\begin{array}{c}\text { (17) } \\
\text { Thick markets }\end{array}$ & $\begin{array}{c}(18) \\
\text { Shallow markets }\end{array}$ \\
\hline Collaborate only (d) & & $\begin{array}{c}0.00 \\
(0.04)\end{array}$ & $\begin{array}{c}0.07 \\
(0.05)\end{array}$ & $\begin{array}{l}-0.11^{*} \\
(0.06)\end{array}$ & $\begin{array}{c}0.01 \\
(0.05)\end{array}$ & $\begin{array}{l}-0.02 \\
(0.06)\end{array}$ \\
\hline Buy only (d) & & $\begin{array}{c}0.04 \\
(0.03)\end{array}$ & $\begin{array}{l}0.11^{* *} \\
(0.05)\end{array}$ & $\begin{array}{l}-0.01 \\
(0.04)\end{array}$ & $\begin{array}{c}0.03 \\
(0.05)\end{array}$ & $\begin{array}{c}0.05 \\
(0.05)\end{array}$ \\
\hline Collaborate and Buy (d) & & $\begin{array}{l}0.15 * * * \\
(0.03)\end{array}$ & $\begin{array}{c}0.07 \\
(0.05)\end{array}$ & $\begin{array}{l}0.19 * * * \\
(0.06)\end{array}$ & $\begin{array}{c}0.08 \\
(0.05)\end{array}$ & $\begin{array}{l}0.21^{* * *} \\
(0.05)\end{array}$ \\
\hline Past performance & $\begin{array}{l}0.43^{* * * *} \\
(0.07)\end{array}$ & $\begin{array}{l}0.43^{* * * *} \\
(0.07)\end{array}$ & $\begin{array}{l}0.54 * * * \\
(0.17)\end{array}$ & $\begin{array}{l}0.41^{* * *} \\
(0.08)\end{array}$ & $\begin{array}{l}0.38 * * * \\
(0.09)\end{array}$ & $\begin{array}{l}0.53^{* * * *} \\
(0.09)\end{array}$ \\
\hline R\&D intensity & $\begin{array}{l}0.40^{* * *} \\
(0.10)\end{array}$ & $\begin{array}{l}0.29 * * * \\
(0.10)\end{array}$ & $\begin{array}{c}1.65 \\
(2.37)\end{array}$ & $\begin{array}{c}5.98 \\
(3.77)\end{array}$ & $\begin{array}{l}0.27^{* *} \\
(0.12)\end{array}$ & $\begin{array}{l}0.64^{* *} \\
(0.25)\end{array}$ \\
\hline Patent stock per employee & $\begin{array}{l}1.04 * * * \\
(0.40)\end{array}$ & $\begin{array}{l}0.98 * * * \\
(0.38)\end{array}$ & $\begin{array}{l}0.76^{* *} \\
(0.31)\end{array}$ & $\begin{array}{c}2.22^{*} \\
(1.24)\end{array}$ & $\begin{array}{l}0.77^{* *} \\
(0.37)\end{array}$ & $\begin{array}{l}2.21^{* *} \\
(0.87)\end{array}$ \\
\hline Export intensity & $\begin{array}{l}0.38 * * * \\
(0.06)\end{array}$ & $\begin{array}{l}0.36^{* * * *} \\
(0.06)\end{array}$ & $\begin{array}{l}0.29 * * * \\
(0.07)\end{array}$ & $\begin{array}{l}0.32 * * * \\
(0.09)\end{array}$ & $\begin{array}{l}0.35^{* * * *} \\
(0.08)\end{array}$ & $\begin{array}{l}0.34^{* * * *} \\
(0.08)\end{array}$ \\
\hline Process innovator (d) & $\begin{array}{l}0.15^{* * *} \\
(0.02)\end{array}$ & $\begin{array}{l}0.13^{* * *} \\
(0.02)\end{array}$ & $\begin{array}{l}0.12 * * * \\
(0.04)\end{array}$ & $\begin{array}{l}0.14^{* * *} \\
(0.03)\end{array}$ & $\begin{array}{l}0.09 * * * \\
(0.03)\end{array}$ & $\begin{array}{l}0.18^{* * * *} \\
(0.04)\end{array}$ \\
\hline No of employees (log) & $\begin{array}{l}0.63^{* * *} \\
(0.01)\end{array}$ & $\begin{array}{l}0.62 * * * \\
(0.01)\end{array}$ & $\begin{array}{l}0.66 * * * \\
(0.02)\end{array}$ & $\begin{array}{l}0.59 * * * \\
(0.02)\end{array}$ & $\begin{array}{l}0.66 * * * \\
(0.02)\end{array}$ & $\begin{array}{l}0.57^{* * * *} \\
(0.02)\end{array}$ \\
\hline Part of group (d) & $\begin{array}{l}0.10^{* * *} \\
(0.03)\end{array}$ & $\begin{array}{l}0.10 * * * \\
(0.03)\end{array}$ & $\begin{array}{l}0.09 * \\
(0.05)\end{array}$ & $\begin{array}{l}0.09 * * \\
(0.04)\end{array}$ & $\begin{array}{c}0.03 \\
(0.04)\end{array}$ & $\begin{array}{l}0.16^{* * *} \\
(0.05)\end{array}$ \\
\hline Firm R\&D - industry R\&D & & & $\begin{array}{l}-1.47 \\
(2.38)\end{array}$ & $\begin{array}{l}-3.11 \\
(3.22)\end{array}$ & & \\
\hline Market thickness & & & & & $\begin{array}{c}1.89 \\
(1.32)\end{array}$ & $\begin{array}{l}-1.21 \\
(1.73)\end{array}$ \\
\hline Industry dummies & included & included & included & included & included & included \\
\hline Survey year dummies & included & included & included & included & included & included \\
\hline Constant & $\begin{array}{l}-1.69 * * * \\
(0.06)\end{array}$ & $\begin{array}{l}-1.70 * * * \\
(0.06)\end{array}$ & $\begin{array}{l}-1.79 * * * \\
(0.12)\end{array}$ & $\begin{array}{l}-1.77 * * * \\
(0.13)\end{array}$ & $\begin{array}{l}-2.00 * * * \\
(0.17)\end{array}$ & $\begin{array}{l}-1.27 * * * \\
(0.34)\end{array}$ \\
\hline Complementarity test & & $\begin{array}{c}\mathrm{F}(1,3413)= \\
3.70^{*}\end{array}$ & $\begin{array}{c}\mathrm{F}(1,1432)= \\
2.06\end{array}$ & $\begin{array}{c}\mathrm{F}(1,2116)= \\
13.80^{* * *}\end{array}$ & $\begin{array}{c}\mathrm{F}(1,1822)= \\
0.26\end{array}$ & $\begin{array}{c}\mathrm{F}(1,1709)= \\
4.56^{* *}\end{array}$ \\
\hline $\begin{array}{l}\mathrm{N} \\
\text { F-statistic / Wald Chi2 }\end{array}$ & $\begin{array}{c}3921 \\
158.94^{* * *}\end{array}$ & $\begin{array}{c}3921 \\
146.24 * * *\end{array}$ & $\begin{array}{c}1593 \\
79.56^{* * *}\end{array}$ & $\begin{array}{c}2328 \\
83.79 * * *\end{array}$ & $\begin{array}{c}2021 \\
78.80 * * *\end{array}$ & $\begin{array}{c}1900 \\
112.45^{* * *}\end{array}$ \\
\hline
\end{tabular}

Coefficients are shown; standard errors in parentheses; (d) dummy variable; ${ }^{*} \mathrm{p}<0.10,{ }^{* *} \mathrm{p}<0.05,{ }^{* * *} \mathrm{p}<0.01$

Industry dummies are jointly significant in each model; survey year dummies are not significant. 


\section{(2) Multinomial probit models for the choice of search strategy}

Following Cassiman and Veugelers (2006), we examine the drivers of the combinations of relational and transactional search by means of bivariate probit and multinomial probit models. The bivariate probit model predicts the likelihood to engage in relational and transactional search. We use a cross-sectional model with standard errors corrected for intra-group (firm) correlation. We are particularly interested whether the two contingency variables technology leadership and market thickness are significantly related to the adoption of relational and transactional search, i.e. the two non-exclusive strategies COLLABORATE and BUY. Table 8 shows the results which provide additional support for the complementarity between relational and transactional search. First, the correlation coefficient of the error terms (rho) provides an indication of whether the two strategies may be jointly influenced by unobserved factors and hence are likely to be chosen together by the firm. Prior research has used rho as an indication of complementarity between certain organizational practices (e.g., Cassiman and Veugelers, 2006). We find this correlation to be positive and significant. Second, we find the variable market thickness to have a negative and significant relationship with both COLLABORATE and BUY, as would be expected. The variable measuring technology leadership is also negatively related to the adoption of both search strategies but insignificant.

Moreover, we use a multinomial probit model instead of a multinomial logit model because it does not assume independence of irrelevant alternatives (IIA) but rather allows the errors to be correlated across choices (Maddala, 1983). Again, we use a cross-sectional model with standard errors corrected for intragroup (firm) correlation. We are particularly interested whether the two contingency variables technology leadership and market thickness are significantly related to the joint adoption of relational and transactional search. To provide further support for Hypotheses 2 and 3, we expect the relationships to be negative and significant but insignificant for the two decisions to only adopt COLLABORATE or BUY. 
Table 9 presents the results of the multinomial probit model which predicts the three exclusive search strategies (with no relational or transactional search being the base outcome). Model 21 contains the control variables as described before and the two contingency variables used to define the group variables. Most importantly, we find no significant relationship between past performance and the choice of search strategy which alleviates concerns regarding potential reverse causality. More R\&D intensive firms are more likely to engage in exclusive relational search as well as in joint relational and transactional search. This underlines the importance of internal investments in research capacities in order to fruitfully engage in collaborative efforts with partners.

A higher patent stock, being a process innovator and firm size are positively associated with all three search strategies while higher export intensity is only positively related to joint relational and transactional search. Being part of a group of firms has no influence. Again, we find the industry dummies to be jointly significantly different from zero while the survey year dummies are not. To provide further evidence in support of Hypotheses 2 and 3 we would expect both contingency variables to be negatively associated with the joint adoption of relational and transactional search. We only find such a negative and significant relationship between market thickness and joint adoption. Firm R\&D intensity in relation to industry R\&D turns out to have the predicted negative sign but no significant relationship with any search strategy. The nature of this test for complementarity is different from the previous one since it does not test a direct link with performance. Instead, it assumes that ceteris paribus managers would always choose two complementary activities simultaneously and that the presence of efficient market mechanisms eliminates sub-optimal choices (Cassiman and Valentini, 2016). The absence of significant findings for this particular complementarity test suggests that the latter has not occurred. In sum, we find additional support for Hypothesis 3 but not for Hypothesis 2. Model 22 additionally contains a number of other variables that characterize the information and resource environment of the firm. We revert to the discussion of the results in the section on endogeneity. 
Furthermore, Table 10 presents the results of four OLS models for which the dependent variables are the exclusive dummy variables used to measure the search strategies, i.e. COLLABORATE and BUY, only BUY, only COLLABORATE, and no COLLABORATE no BUY. To find additional support for Hypotheses 2 and 3, we would again expect the variables for technology leadership and market thickness to be negatively related to the joint adoption strategy (COLLABORATE and BUY). In fact, we find that both variables are negatively related to the joint adoption even though they are insignificant $(\mathrm{p}=0.283$ for technology leadership; $\mathrm{p}=0.106$ for market thickness). These results mirror the findings from the bivariate probit and multinomial probit models. 
Table 8: Bivariate probit model for the choice of search strategy

\begin{tabular}{|c|c|c|c|c|}
\hline & \multicolumn{2}{|c|}{ (19) } & \multicolumn{2}{|c|}{ (20) } \\
\hline & COLLABORATE & BUY & COLLABORATE & BUY \\
\hline \multirow[t]{2}{*}{ Past performance } & 0.01 & 0.01 & 0.05 & 0.03 \\
\hline & $(0.04)$ & $(0.04)$ & $(0.04)$ & $(0.04)$ \\
\hline \multirow[t]{2}{*}{$\mathrm{R} \& \mathrm{D}$ intensity } & $7.87 * *$ & 5.79 & $7.44 *$ & 5.66 \\
\hline & (3.99) & (3.95) & $(4.23)$ & $(4.06)$ \\
\hline \multirow[t]{2}{*}{ Patent stock per employee } & $3.33 * * *$ & 0.88 & $2.83^{* * *}$ & 0.6 \\
\hline & $(0.94)$ & $(0.73)$ & $(0.88)$ & $(0.66)$ \\
\hline \multirow[t]{2}{*}{ Export intensity } & $0.28 * * *$ & $0.24 * *$ & $0.32 * * *$ & $0.24 * *$ \\
\hline & $(0.10)$ & $(0.09)$ & $(0.10)$ & $(0.09)$ \\
\hline \multirow[t]{2}{*}{ Process innovator (d) } & $0.24 * * *$ & $0.26 * * *$ & $0.18 * * *$ & $0.14^{* * *}$ \\
\hline & $(0.05)$ & $(0.04)$ & $(0.05)$ & $(0.05)$ \\
\hline \multirow[t]{2}{*}{ No of employees (log) } & $0.16^{* * *}$ & $0.15^{* * *}$ & $0.13^{* * *}$ & $0.12 * * *$ \\
\hline & $(0.02)$ & $(0.02)$ & $(0.02)$ & $(0.02)$ \\
\hline \multirow[t]{2}{*}{ Part of group (d) } & -0.03 & 0.07 & 0.04 & 0.08 \\
\hline & $(0.05)$ & $(0.05)$ & $(0.06)$ & $(0.05)$ \\
\hline Industry dummies & included & included & included & included \\
\hline Survey year dummies & included & included & included & included \\
\hline \multirow[t]{2}{*}{ Firm R\&D - industry R\&D } & -3.89 & -4.43 & -4.97 & -4.95 \\
\hline & $(4.00)$ & (3.96) & $(4.24)$ & $(4.06)$ \\
\hline \multirow[t]{2}{*}{ Market thickness } & $-1.86 *$ & $-1.60 *$ & $-1.92 *$ & $-1.52 *$ \\
\hline & $(0.98)$ & $(0.87)$ & $(1.08)$ & $(0.89)$ \\
\hline \multirow[t]{2}{*}{ Basic R\&D reliance } & & & $0.51 * * *$ & $0.40 * * *$ \\
\hline & & & $(0.07)$ & $(0.06)$ \\
\hline \multirow[t]{2}{*}{ Innovation subsidy received (d) } & & & $1.03^{* * *}$ & $0.27 * * *$ \\
\hline & & & $(0.05)$ & $(0.05)$ \\
\hline \multirow[t]{2}{*}{ Competitor information } & & & $0.07 * * *$ & $0.12 * * *$ \\
\hline & & & $(0.03)$ & $(0.02)$ \\
\hline \multirow[t]{2}{*}{ Complementary assets (d) } & & & $0.13^{* *}$ & $0.47 * * *$ \\
\hline & & & $(0.06)$ & $(0.05)$ \\
\hline \multirow[t]{2}{*}{ Constant } & $-0.76 * * *$ & $-0.79 * * *$ & $-1.71 * * *$ & $-1.60 * * *$ \\
\hline & $(0.20)$ & $(0.19)$ & $(0.23)$ & $(0.20)$ \\
\hline $\mathrm{N}$ & \multirow{2}{*}{\multicolumn{2}{|c|}{$\begin{array}{c}3921 \\
684.15^{* * *}\end{array}$}} & \multirow{2}{*}{\multicolumn{2}{|c|}{$\begin{array}{c}3921 \\
1352.80^{* * * *}\end{array}$}} \\
\hline LR Chi2 & & & & \\
\hline
\end{tabular}


Table 9: Multinomial probit model for the choice of search strategy

\begin{tabular}{|c|c|c|c|c|c|c|}
\hline & \multicolumn{3}{|c|}{$(21)$} & \multicolumn{3}{|c|}{$(22)$} \\
\hline & Only COLL & Only BUY & COLL and BUY & Only COLL & Only BUY & COLL and BUY \\
\hline \multirow[t]{2}{*}{ Past performance } & 0.04 & 0.03 & 0 & 0.09 & 0.05 & 0.07 \\
\hline & $(0.07)$ & $(0.05)$ & $(0.06)$ & $(0.07)$ & $(0.05)$ & $(0.06)$ \\
\hline \multirow[t]{2}{*}{ R\&D intensity } & 9.26 & 5.38 & $12.48^{* *}$ & 8.39 & 5.54 & $13.03 *$ \\
\hline & $(6.89)$ & $(6.54)$ & $(6.32)$ & $(7.11)$ & $(6.80)$ & $(6.85)$ \\
\hline \multirow[t]{2}{*}{ Patent stock per employee } & $6.19 * * *$ & $3.63^{*}$ & $5.84 * * *$ & $5.27 * * *$ & $3.02 *$ & $4.64 * * *$ \\
\hline & $(2.00)$ & $(1.95)$ & $(1.96)$ & $(1.72)$ & $(1.75)$ & $(1.67)$ \\
\hline \multirow[t]{2}{*}{ Export intensity } & 0.16 & 0.1 & $0.47 * * *$ & 0.21 & 0.14 & $0.58 * * *$ \\
\hline & $(0.17)$ & $(0.16)$ & $(0.15)$ & $(0.17)$ & $(0.16)$ & $(0.16)$ \\
\hline \multirow[t]{2}{*}{ Process innovator (d) } & $0.21^{* * *}$ & $0.26 * * *$ & $0.50 * * *$ & 0.14 & 0.1 & $0.34^{* * *}$ \\
\hline & $(0.08)$ & $(0.07)$ & $(0.07)$ & $(0.08)$ & $(0.07)$ & $(0.08)$ \\
\hline \multirow[t]{2}{*}{ No of employees (log) } & $0.16^{* * *}$ & $0.16^{* * *}$ & $0.31 * * *$ & $0.14^{* * *}$ & $0.14^{* * *}$ & $0.27 * * *$ \\
\hline & $(0.03)$ & $(0.03)$ & $(0.03)$ & $(0.03)$ & $(0.03)$ & $(0.03)$ \\
\hline \multirow[t]{2}{*}{ Part of group (d) } & -0.06 & 0.08 & 0.02 & 0.04 & 0.09 & 0.14 \\
\hline & $(0.09)$ & $(0.08)$ & $(0.08)$ & $(0.09)$ & $(0.08)$ & $(0.09)$ \\
\hline Industry dummies & included & included & included & included & included & included \\
\hline Survey year dummies & included & included & included & included & included & included \\
\hline \multirow[t]{2}{*}{ Firm R\&D - industry R\&D } & -4.95 & -4.81 & -7.02 & -5.88 & -5.43 & -9.7 \\
\hline & $(6.92)$ & (6.56) & $(6.34)$ & (7.13) & $(6.81)$ & $(6.86)$ \\
\hline \multirow[t]{2}{*}{ Market thickness } & -2.58 & -1.85 & $-2.99 * *$ & -2.63 & -1.88 & $-3.23^{* *}$ \\
\hline & $(1.77)$ & $(1.32)$ & $(1.49)$ & $(1.89)$ & $(1.33)$ & $(1.64)$ \\
\hline \multirow[t]{2}{*}{ Basic $R \& D$ reliance } & & & & $0.54^{* * *}$ & $0.42^{* * *}$ & $0.96 * * *$ \\
\hline & & & & $(0.12)$ & $(0.11)$ & $(0.13)$ \\
\hline \multirow[t]{2}{*}{ Innovation subsidy received (d) } & & & & $1.22^{* * *}$ & $0.17^{* *}$ & $1.34^{* * *}$ \\
\hline & & & & $(0.09)$ & $(0.09)$ & $(0.08)$ \\
\hline \multirow[t]{2}{*}{ Competitor information } & & & & 0.05 & $0.13^{* * *}$ & $0.20 * * *$ \\
\hline & & & & $(0.04)$ & $(0.04)$ & $(0.04)$ \\
\hline \multirow[t]{2}{*}{ Complementary assets (d) } & & & & 0.13 & $0.62 * * *$ & $0.63^{* * *}$ \\
\hline & & & & $(0.09)$ & $(0.08)$ & $(0.10)$ \\
\hline \multirow[t]{2}{*}{ Constant } & $-0.94 * * *$ & $-1.04 * * *$ & $-1.58 * * *$ & $-1.91^{* * *}$ & $-1.86 * * *$ & $-3.50 * * *$ \\
\hline & $(0.35)$ & $(0.31)$ & $(0.31)$ & $(0.38)$ & $(0.33)$ & $(0.37)$ \\
\hline $\mathrm{N}$ & & 3921 & & & 3921 & \\
\hline LR Chi2 & & $665.47 * * *$ & & & $1186.98^{* * *}$ & \\
\hline
\end{tabular}


Table 10: OLS regression results for the choice of search strategy

\begin{tabular}{|c|c|c|c|c|}
\hline & $\begin{array}{c}\text { (23) } \\
\text { COLL and BUY }\end{array}$ & $\begin{array}{c}(24) \\
\text { Only BUY }\end{array}$ & $\begin{array}{c}(25) \\
\text { Only COLL }\end{array}$ & $\begin{array}{c}(26) \\
\text { No COLL no BUY }\end{array}$ \\
\hline Past performance & $\begin{array}{c}0.01 \\
(0.01)\end{array}$ & $\begin{array}{c}0 \\
(0.01)\end{array}$ & $\begin{array}{c}0.01 \\
(0.01)\end{array}$ & $\begin{array}{l}-0.02 \\
(0.01)\end{array}$ \\
\hline R\&D intensity & $\begin{array}{c}1.87 \\
(1.28)\end{array}$ & $\begin{array}{c}0.09 \\
(1.21)\end{array}$ & $\begin{array}{c}0.18 \\
(1.06)\end{array}$ & $\begin{array}{l}-2.14^{*} \\
(1.23)\end{array}$ \\
\hline Patent stock per employee & $\begin{array}{c}0.23 \\
(0.22)\end{array}$ & $\begin{array}{l}-0.01 \\
(0.13)\end{array}$ & $\begin{array}{c}0.35^{*} \\
(0.19)\end{array}$ & $\begin{array}{l}-0.57 * * * \\
(0.17)\end{array}$ \\
\hline Export intensity & $\begin{array}{l}0.11 * * * \\
(0.03)\end{array}$ & $\begin{array}{l}-0.03 \\
(0.03)\end{array}$ & $\begin{array}{c}0 \\
(0.02)\end{array}$ & $\begin{array}{l}-0.08 * * * \\
(0.03)\end{array}$ \\
\hline Process innovator (d) & $\begin{array}{l}0.05 * * * \\
(0.01)\end{array}$ & $\begin{array}{c}0 \\
(0.01)\end{array}$ & $\begin{array}{c}0 \\
(0.01)\end{array}$ & $\begin{array}{l}-0.04 * * * \\
(0.02)\end{array}$ \\
\hline No of employees (log) & $\begin{array}{l}0.04^{* * *} \\
(0.00)\end{array}$ & $\begin{array}{c}0.01 \\
(0.01)\end{array}$ & $\begin{array}{c}0 \\
(0.00)\end{array}$ & $\begin{array}{l}-0.04^{* * *} \\
(0.01)\end{array}$ \\
\hline Part of group (d) & $\begin{array}{c}0.02 \\
(0.01)\end{array}$ & $\begin{array}{c}0.01 \\
(0.02)\end{array}$ & $\begin{array}{c}0 \\
(0.01)\end{array}$ & $\begin{array}{l}-0.03 \\
(0.02)\end{array}$ \\
\hline Industry dummies & included & included & included & included \\
\hline Survey year dummies & included & included & included & included \\
\hline Firm R\&D - industry R\&D & $\begin{array}{l}-1.38 \\
(1.28)\end{array}$ & $\begin{array}{l}-0.33 \\
(1.21)\end{array}$ & $\begin{array}{l}-0.07 \\
(1.07)\end{array}$ & $\begin{array}{c}1.78 \\
(1.23)\end{array}$ \\
\hline Market thickness & $\begin{array}{l}-0.36 \\
(0.22)\end{array}$ & $\begin{array}{l}-0.16 \\
(0.27)\end{array}$ & $\begin{array}{c}-0.1 \\
(0.18)\end{array}$ & $\begin{array}{l}0.63^{* *} \\
(0.29)\end{array}$ \\
\hline Basic R\&D reliance & $\begin{array}{l}0.14^{* * *} \\
(0.01)\end{array}$ & $\begin{array}{c}0 \\
(0.01)\end{array}$ & $\begin{array}{c}0 \\
(0.01)\end{array}$ & $\begin{array}{l}-0.13^{* * *} \\
(0.02)\end{array}$ \\
\hline Innovation subsidy received (d) & $\begin{array}{l}0.23^{* * *} \\
(0.02)\end{array}$ & $\begin{array}{l}-0.13^{* * *} \\
(0.02)\end{array}$ & $\begin{array}{l}0.13^{* * *} \\
(0.01)\end{array}$ & $\begin{array}{l}-0.23^{* * *} \\
(0.02)\end{array}$ \\
\hline Competitor information & $\begin{array}{l}0.03 * * * \\
(0.01)\end{array}$ & $\begin{array}{l}0.02 * * \\
(0.01)\end{array}$ & $\begin{array}{l}-0.01 \\
(0.01)\end{array}$ & $\begin{array}{l}-0.03 * * * \\
(0.01)\end{array}$ \\
\hline Complementary assets (d) & $\begin{array}{l}0.07 * * * \\
(0.01)\end{array}$ & $\begin{array}{l}0.10 * * * \\
(0.02)\end{array}$ & $\begin{array}{l}-0.03^{* *} \\
(0.01)\end{array}$ & $\begin{array}{l}-0.13^{* * *} \\
(0.02)\end{array}$ \\
\hline Constant & $\begin{array}{l}-0.21^{* * *} \\
(0.06)\end{array}$ & $\begin{array}{l}0.15^{* *} \\
(0.06)\end{array}$ & $\begin{array}{l}0.20 * * * \\
(0.05)\end{array}$ & $\begin{array}{l}0.87 * * * \\
(0.06)\end{array}$ \\
\hline $\begin{array}{l}\mathrm{N} \\
\mathrm{F}(34,3413)\end{array}$ & $\begin{array}{c}3921 \\
37.52^{* * *}\end{array}$ & $\begin{array}{c}3921 \\
8.36^{* * *}\end{array}$ & $\begin{array}{c}3921 \\
5.51 * * *\end{array}$ & $\begin{array}{c}3921 \\
46.49 * * *\end{array}$ \\
\hline
\end{tabular}

Coefficients are shown; standard errors in parentheses; (d) dummy variable; ${ }^{*} \mathrm{p}<0.10,{ }^{* *} \mathrm{p}<0.05,{ }^{* * *} \mathrm{p}<0.01$.

Industry dummies are jointly significant in each model; survey year dummies are not significant. 


\section{(3) Pooled and random-effects Tobit regression models using alternative measures}

As mentioned before, we present the results of using alternative measures in the regression, such as different definitions of market thickness and an expression of the dependent variable as a ratio by dividing new product sales by the firm's total sales. Models 27 to 30 of Table 11 show the results of the innovation performance models using the alternative measure of market thickness (i.e. industry expenditures for external R\&D and in-licensing divided by industry sales). Both the pooled and random-effects Tobit estimations provide support for the complementarity between relational and transactional search. Models 31 and 32 use a measure of market thickness that excludes external R\&D expenditure from the numerator in order to measure market thickness only through licensing. Again, we find support for complementarity in the sample for shallow market thickness.

Models 33 and 34 of Table 12 show the results when the share of sales with new products is used as the dependent variable. Again, we find robust results confirming complementarity in both the pooled and random-effects model. Models 35 and 36 contain both variables used to define the split samples. They turn out to have an insignificant relationship with innovation performance while the complementarity test remains robust. 
Table 11: Pooled and random-effects Tobit regression results for innovation performance (robustness checks)

\begin{tabular}{|c|c|c|c|c|c|c|}
\hline & $\begin{array}{c}\text { (27) } \\
\text { Pooled } \\
\text { Thick markets } \\
\end{array}$ & $\begin{array}{c}\text { (28) } \\
\text { Pooled } \\
\text { Shallow markets }\end{array}$ & $\begin{array}{c}\text { (29) } \\
\text { RE } \\
\text { Thick markets } \\
\end{array}$ & $\begin{array}{c}\text { (30) } \\
\text { RE } \\
\text { Shallow markets } \\
\end{array}$ & $\begin{array}{c}\text { (31) } \\
\text { RE } \\
\text { Thick markets } \\
\end{array}$ & $\begin{array}{c}\text { (32) } \\
\text { RE } \\
\text { Shallow markets }\end{array}$ \\
\hline Collaborate only (d) & $\begin{array}{c}0.05 \\
(0.05)\end{array}$ & $\begin{array}{l}-0.04 \\
(0.07)\end{array}$ & $\begin{array}{c}0.06 \\
(0.05)\end{array}$ & $\begin{array}{l}-0.04 \\
(0.07)\end{array}$ & $\begin{array}{c}0.01 \\
(0.06)\end{array}$ & $\begin{array}{c}-0.02 \\
(0.06)\end{array}$ \\
\hline Buy only (d) & $\begin{array}{l}0.05 \\
(0.05)\end{array}$ & $\begin{array}{l}0.03 \\
(0.05)\end{array}$ & $\begin{array}{c}0.05 \\
(0.05)\end{array}$ & $\begin{array}{c}0.02 \\
(0.04)\end{array}$ & $\begin{array}{c}0.02 \\
(0.04)\end{array}$ & $\begin{array}{l}0.05 \\
(0.05)\end{array}$ \\
\hline Collaborate and Buy (d) & $\begin{array}{l}0.15^{* * *} \\
(0.04)\end{array}$ & $\begin{array}{l}0.15^{* * *} \\
(0.06)\end{array}$ & $\begin{array}{l}0.14^{* * *} \\
(0.04)\end{array}$ & $\begin{array}{l}0.14^{* * *} \\
(0.05)\end{array}$ & $\begin{array}{l}0.08^{*} \\
(0.05)\end{array}$ & $\begin{array}{l}0.16^{* * *} \\
(0.05)\end{array}$ \\
\hline Past performance & $\begin{array}{l}1.01 * * * \\
(0.21)\end{array}$ & $\begin{array}{l}0.34 * * * \\
(0.06)\end{array}$ & $\begin{array}{l}0.92 * * * \\
(0.05)\end{array}$ & $\begin{array}{l}0.33 * * * \\
(0.02)\end{array}$ & $\begin{array}{l}0.31 * * * \\
(0.02)\end{array}$ & $\begin{array}{l}0.82^{* * *} \\
(0.04)\end{array}$ \\
\hline R\&D intensity & $\begin{array}{l}0.41^{* * *} \\
(0.12)\end{array}$ & $\begin{array}{l}0.46^{* *} \\
(0.22)\end{array}$ & $\begin{array}{l}0.35^{* *} \\
(0.14)\end{array}$ & $\begin{array}{c}0.47 \\
(0.35)\end{array}$ & $\begin{array}{l}0.26 \\
(0.17)\end{array}$ & $\begin{array}{l}0.52^{* *} \\
(0.22)\end{array}$ \\
\hline Patent stock per employee & $\begin{array}{l}0.76^{* *} \\
(0.32)\end{array}$ & $\begin{array}{l}3.09 * * * \\
(0.70)\end{array}$ & $\begin{array}{l}0.72^{* *} \\
(0.35)\end{array}$ & $\begin{array}{l}3.42 * * * \\
(1.01)\end{array}$ & $\begin{array}{c}0.59 \\
(0.44)\end{array}$ & $\begin{array}{l}1.46^{* * *} \\
(0.54)\end{array}$ \\
\hline Export intensity & $\begin{array}{l}0.26 * * * \\
(0.08)\end{array}$ & $\begin{array}{l}0.36 * * * \\
(0.09)\end{array}$ & $\begin{array}{l}0.26 * * * \\
(0.07)\end{array}$ & $\begin{array}{l}0.37 * * * \\
(0.09)\end{array}$ & $\begin{array}{l}0.33^{* * *} \\
(0.08)\end{array}$ & $\begin{array}{l}0.33^{* * *} \\
(0.07)\end{array}$ \\
\hline Process innovator (d) & $\begin{array}{l}0.15^{* * *} \\
(0.03)\end{array}$ & $\begin{array}{l}0.13^{* * *} \\
(0.04)\end{array}$ & $\begin{array}{l}0.17 * * * \\
(0.03)\end{array}$ & $\begin{array}{l}0.12^{* * *} \\
(0.04)\end{array}$ & $\begin{array}{l}0.12 * * * \\
(0.04)\end{array}$ & $\begin{array}{l}0.17 * * * \\
(0.04)\end{array}$ \\
\hline No of employees (log) & $\begin{array}{l}0.67 * * * \\
(0.02)\end{array}$ & $\begin{array}{l}0.57 * * * \\
(0.02)\end{array}$ & $\begin{array}{l}0.66 * * * \\
(0.01)\end{array}$ & $\begin{array}{l}0.58 * * * \\
(0.01)\end{array}$ & $\begin{array}{l}0.60 * * * \\
(0.01)\end{array}$ & $\begin{array}{l}0.64 * * * \\
(0.01)\end{array}$ \\
\hline Part of group (d) & $\begin{array}{l}-0.01 \\
(0.04)\end{array}$ & $\begin{array}{l}0.15^{* * *} \\
(0.05)\end{array}$ & $\begin{array}{c}0 \\
(0.04)\end{array}$ & $\begin{array}{l}0.13^{* * *} \\
(0.04)\end{array}$ & $\begin{array}{l}0.09^{* *} \\
(0.04)\end{array}$ & $\begin{array}{c}0.06 \\
(0.04)\end{array}$ \\
\hline Market thickness (alternative measures) & $\begin{array}{c}17.72 \\
(14.11)\end{array}$ & $\begin{array}{l}-67.28 \\
(48.52)\end{array}$ & $\begin{array}{c}17.54 \\
(12.06)\end{array}$ & $\begin{array}{c}-56.6 \\
(43.39)\end{array}$ & $\begin{array}{c}0.58 \\
(1.48)\end{array}$ & $\begin{array}{l}-10.98^{* *} \\
(4.56)\end{array}$ \\
\hline Industry dummies & included & included & included & included & included & included \\
\hline Survey year dummies & included & included & included & included & included & included \\
\hline Constant & $\begin{array}{l}-2.12 * * * \\
(0.14)\end{array}$ & $\begin{array}{l}-1.97 * * * \\
(0.10)\end{array}$ & $\begin{array}{l}-2.08 * * * \\
(0.12)\end{array}$ & $\begin{array}{l}-1.98^{* * *} \\
(0.09)\end{array}$ & $\begin{array}{l}-1.63^{* * *} \\
(0.10)\end{array}$ & $\begin{array}{l}-1.68 * * * \\
(0.13)\end{array}$ \\
\hline Complementarity test & $\begin{array}{c}\mathrm{F}(1,1941)= \\
0.64\end{array}$ & $\begin{array}{c}\mathrm{F}(1,1931)= \\
3.29 *\end{array}$ & $\begin{array}{c}\text { Chi2(1)= } \\
0.23\end{array}$ & $\begin{array}{c}\text { Chi2(1)= } \\
\text { 3.86** }\end{array}$ & $\begin{array}{c}\text { Chi2(1)= } \\
0.50\end{array}$ & $\begin{array}{c}\text { Chi2(1)= } \\
3.20^{*}\end{array}$ \\
\hline $\begin{array}{l}\mathrm{N} \\
\text { F-statistic / Wald Chi2 }\end{array}$ & $\begin{array}{c}1962 \\
133.19 * * *\end{array}$ & $\begin{array}{c}1959 \\
89.99 * * *\end{array}$ & $\begin{array}{c}1962 \\
6142.04 * * *\end{array}$ & $\begin{array}{c}1959 \\
3969.83^{* * *}\end{array}$ & $\begin{array}{c}1973 \\
4348.52 * * *\end{array}$ & $\begin{array}{c}1948 \\
5804.41^{* * *}\end{array}$ \\
\hline
\end{tabular}

Coefficients are shown; standard errors in parentheses; (d) dummy variable; ${ }^{*} \mathrm{p}<0.10,{ }^{* *} \mathrm{p}<0.05,{ }^{* * *} \mathrm{p}<0.01$.

Industry dummies are jointly significant in each model; survey year dummies are not significant. 
Table 12: Pooled and random-effects Tobit regression results for innovation performance (robustness checks)

\begin{tabular}{|c|c|c|c|c|c|c|}
\hline & $\begin{array}{c}\text { (33) } \\
\text { Pooled } \\
\text { Share of sales }\end{array}$ & $\begin{array}{c}\text { (34) } \\
\text { RE } \\
\text { Share of sales }\end{array}$ & $\begin{array}{c}\text { (35) } \\
\text { Pooled } \\
\text { w/ cont. vars. }\end{array}$ & $\begin{array}{c}\text { (36) } \\
\text { RE } \\
\text { w/ cont. vars. }\end{array}$ & $\begin{array}{c}\text { (37) } \\
\text { Pooled } \\
\text { Instrumented }\end{array}$ & $\begin{array}{c}\text { (38) } \\
\text { RE } \\
\text { Instrumented }\end{array}$ \\
\hline Collaborate only (d) & $\begin{array}{l}-0.01 \\
(0.01)\end{array}$ & $\begin{array}{c}0.00 \\
(0.01)\end{array}$ & $\begin{array}{l}-0.01 \\
(0.04)\end{array}$ & $\begin{array}{c}0.01 \\
(0.04)\end{array}$ & $\begin{array}{l}-1.60 * * * \\
(0.24)\end{array}$ & $\begin{array}{l}-1.40 * * * \\
(0.23)\end{array}$ \\
\hline Buy only (d) & $\begin{array}{c}0.01 \\
(0.01)\end{array}$ & $\begin{array}{c}0.00 \\
(0.01)\end{array}$ & $\begin{array}{c}0.05 \\
(0.03)\end{array}$ & $\begin{array}{c}0.03 \\
(0.03)\end{array}$ & $\begin{array}{l}-1.02 * * * \\
(0.24)\end{array}$ & $\begin{array}{l}-0.92 * * * \\
(0.20)\end{array}$ \\
\hline Collaborate and Buy (d) & $\begin{array}{l}0.03^{* *} \\
(0.01)\end{array}$ & $\begin{array}{l}0.03^{* *} \\
(0.01)\end{array}$ & $\begin{array}{l}0.15^{* * * *} \\
(0.04)\end{array}$ & $\begin{array}{l}0.14^{* * * *} \\
(0.03)\end{array}$ & $\begin{array}{l}0.63 * * * \\
(0.12)\end{array}$ & $\begin{array}{l}0.59 * * * \\
(0.11)\end{array}$ \\
\hline Past performance & $\begin{array}{l}-0.01^{*} \\
(0.00)\end{array}$ & $\begin{array}{l}-0.01 \\
(0.01)\end{array}$ & $\begin{array}{l}0.43^{* * * *} \\
(0.07)\end{array}$ & $\begin{array}{l}0.40 * * * \\
(0.02)\end{array}$ & $\begin{array}{l}0.45^{* * *} \\
(0.08)\end{array}$ & $\begin{array}{l}0.42^{* * * *} \\
(0.02)\end{array}$ \\
\hline R\&D intensity & $\begin{array}{l}0.50 * * * \\
(0.06)\end{array}$ & $\begin{array}{l}0.47 * * * \\
(0.04)\end{array}$ & $\begin{array}{l}1.82 \\
(1.87)\end{array}$ & $\begin{array}{l}1.79 \\
(2.21)\end{array}$ & $\begin{array}{l}-0.11 \\
(0.13)\end{array}$ & $\begin{array}{l}-0.12 \\
(0.15)\end{array}$ \\
\hline Patent stock per employee & $\begin{array}{l}0.54^{* * * *} \\
(0.11)\end{array}$ & $\begin{array}{l}0.52^{* * *} \\
(0.11)\end{array}$ & $\begin{array}{l}1.01^{* * * *} \\
(0.38)\end{array}$ & $\begin{array}{l}0.95 * * * \\
(0.35)\end{array}$ & $\begin{array}{l}1.38^{* * * *} \\
(0.40)\end{array}$ & $\begin{array}{l}1.26^{* * * *} \\
(0.35)\end{array}$ \\
\hline Export intensity & $\begin{array}{l}0.05^{* *} \\
(0.02)\end{array}$ & $\begin{array}{l}0.05^{* * * *} \\
(0.02)\end{array}$ & $\begin{array}{l}0.36 * * * \\
(0.06)\end{array}$ & $\begin{array}{l}0.35^{* * * *} \\
(0.06)\end{array}$ & $\begin{array}{l}0.26 * * * \\
(0.06)\end{array}$ & $\begin{array}{l}0.27 * * * \\
(0.06)\end{array}$ \\
\hline Process innovator (d) & $\begin{array}{l}0.05 * * * \\
(0.01)\end{array}$ & $\begin{array}{l}0.05^{* * *} \\
(0.01)\end{array}$ & $\begin{array}{l}0.14^{* * * *} \\
(0.02)\end{array}$ & $\begin{array}{l}0.14^{* * * *} \\
(0.03)\end{array}$ & $\begin{array}{l}0.11^{* * *} \\
(0.03)\end{array}$ & $\begin{array}{l}0.11^{* * * *} \\
(0.03)\end{array}$ \\
\hline No of employees (log) & $\begin{array}{l}-0.02 * * * \\
(0.00)\end{array}$ & $\begin{array}{l}-0.03^{* * *} \\
(0.00)\end{array}$ & $\begin{array}{l}0.62 * * * \\
(0.01)\end{array}$ & $\begin{array}{l}0.62 * * * \\
(0.01)\end{array}$ & $\begin{array}{l}0.61 * * * \\
(0.02)\end{array}$ & $\begin{array}{l}0.61^{* * *} \\
(0.01)\end{array}$ \\
\hline Part of group (d) & $\begin{array}{c}0.00 \\
(0.01)\end{array}$ & $\begin{array}{c}0.00 \\
(0.01)\end{array}$ & $\begin{array}{l}0.09 * * * \\
(0.03)\end{array}$ & $\begin{array}{l}0.09 * * * \\
(0.03)\end{array}$ & $\begin{array}{l}0.09 * * * \\
(0.03)\end{array}$ & $\begin{array}{l}0.09 * * * \\
(0.03)\end{array}$ \\
\hline Firm R\&D - industry R\&D & & & $\begin{array}{l}-1.52 \\
(1.88)\end{array}$ & $\begin{array}{l}-1.51 \\
(2.21)\end{array}$ & & \\
\hline Market thickness & & & $\begin{array}{c}0.11 \\
(0.54)\end{array}$ & $\begin{array}{c}0.30 \\
(0.49)\end{array}$ & & \\
\hline Industry dummies & included & included & included & included & included & included \\
\hline Survey year dummies & included & included & included & included & included & included \\
\hline Constant & $\begin{array}{l}0.30 * * * \\
(0.02)\end{array}$ & $\begin{array}{l}0.31^{* * *} \\
(0.02)\end{array}$ & $\begin{array}{l}-1.79 * * * \\
(0.10)\end{array}$ & $\begin{array}{l}-1.80 * * * \\
(0.11)\end{array}$ & $\begin{array}{l}-1.25 * * * \\
(0.08)\end{array}$ & $\begin{array}{l}-1.29 * * * \\
(0.09)\end{array}$ \\
\hline Complementarity test & $\begin{array}{c}\mathrm{F}(1,3890)= \\
3.51^{*}\end{array}$ & $\begin{array}{c}\text { Chi2(1)= } \\
2.87 *\end{array}$ & $\begin{array}{c}\mathrm{F}(1,3888)= \\
4.26^{* *}\end{array}$ & $\begin{array}{c}\text { Chi2(1)= } \\
\text { 3.16* }\end{array}$ & $\begin{array}{c}\mathrm{F}(1,3890)= \\
53.70^{* * * *}\end{array}$ & $\begin{array}{l}\text { Chi2(1)= } \\
53.70^{* * *}\end{array}$ \\
\hline $\begin{array}{l}\mathrm{N} \\
\text { F-statistic / Wald Chi2 }\end{array}$ & $\begin{array}{c}3921 \\
18.64^{* * *}\end{array}$ & $\begin{array}{c}3921 \\
548.46^{* * *}\end{array}$ & $\begin{array}{c}3921 \\
137.71^{* * *}\end{array}$ & $\begin{array}{c}3921 \\
9195.25^{* * *}\end{array}$ & $\begin{array}{c}3921 \\
167.78^{* * *}\end{array}$ & $\begin{array}{c}3921 \\
9478.33^{* * *}\end{array}$ \\
\hline
\end{tabular}

Coefficients are shown; standard errors in parentheses; (d) dummy variable; ${ }^{*} \mathrm{p}<0.10,{ }^{* *} \mathrm{p}<0.05,{ }^{* * *} \mathrm{p}<0.01$.

Industry dummies are jointly significant in each model; survey year dummies are not significant. 


\section{(4) Controlling for endogeneity of the search strategies adopted}

Finally, we revert to the issue of endogeneity. First of all, the multinomial probit models have demonstrated that past performance is unrelated to the choice of search strategy which suggests that there are no issues regarding potential reverse causality. Including past performance in the innovation performance models also helps reducing unobserved heterogeneity of the sample firms. Moreover, the multinomial probit models allow the calculation of predicted values of the exclusive innovation strategies that we use as instruments in the innovation performance models. This approach requires the identification of variables that are related to the adoption of a particular search strategy without affecting innovation performance (Cassiman and Veugelers, 2006). We argue that the measure of market thickness fulfills this criterion. A thick market for technology affects the choice of search strategy of all firms in an industry. However, since all firms in the industry are affected by the same market conditions, market thickness is unlikely to affect the innovation performance of any particular firm.

Models 35 and 36 in Table 12 support this line of reasoning. They show that there is no significant relationship between market thickness and innovation performance while there is a significant negative association with the joint adoption of relational and transactional search in the multinomial probit model in Table 9. Moreover, we include two more potential instrumental variables in the multinomial probit model: whether the firm has received any government innovation subsidy and whether the firm simultaneously invested into complementary assets for the introduction of product or process innovations (including machinery, facilities, and IT). Both are likely to affect the choice of search strategy. We expect innovation subsidies to have a positive association with the exclusive and joint adoption of relational search since many subsidy programs are directed towards consortia of collaborating firms. We expect investments into complementary assets to be related to exclusive and joint adoption of transactional search since such assets may help firms appropriate returns from innovation based on rather generic knowledge available on markets for technology. Both variables should however not affect innovation 
performance directly. ${ }^{13}$ Besides these potential instruments, we follow Cassiman and Veugelers (2006) and include two variables in the multinomial probit model that have been shown to affect the choice of innovation strategy: basic R\&D reliance (defined as the importance of universities and research institutes as source of knowledge relative to customers and suppliers) and the reliance on competitor knowledge as a source of information. We expect basic $R \& D$ reliance to be particularly related to the exclusive and joint adoption of relational search (because relational search promises to yield more novel knowledge compared to transactional search) and reliance on competitor knowledge to be associated with transactional search (because firms may need to in-license technology from their competitors). Model 22 in Table 9 shows the results. Besides its importance for relational search, basic R\&D reliance turns out to be associated with transactional search. The results for the remaining variables confirm our expectations.

In the final step to control for endogeneity, we use the predicted probabilities from the multinomial probit model as instruments for the three search strategies in the innovation performance models. The success of this approach depends on the predictive power of the multinomial probit model. While the predictive power of the model is relatively poor with only $56 \%$ of all cases being correctly predicted, it is similar to prior research using this approach (Cassiman and Veugelers, 2006). Models 37 and 38 of Table 12 show the results for the instrumented search strategies. When we use the predicted values as instruments in the innovation performance models, both the coefficients and the test for complementarity provide support for our main hypothesis.

\footnotetext{
${ }^{13}$ In an auxiliary regression, which is available from the authors upon request, we confirm that there is no statistically significant relationship between the two variables and innovation performance.
} 